\title{
Supporting Information \\ Mechanistic Framework and Effects of High Coverage in Vinyl Acetate Synthesis
}

\author{
Zhaoru Zha, Prashant Deshlahra* \\ Department of Chemical and Biological Engineering, Tufts University, Medford, \\ Massachusetts 02155, USA \\ *Email: prashant.deshlahra@tufts.edu
}

\section{Contents}

S1. TEM images of $1 \mathrm{wt} . \% \mathrm{Pd} / \mathrm{SiO}_{2}$ before and after reaction

S2. IR spectra for $1 \mathrm{wt} . \% \mathrm{Pd} / \mathrm{SiO}_{2}$ at reaction conditions

S3. Effect of the size of catalyst aggregates on rate and selectivity

S4. Effect $\mathrm{H}_{2}$ treatment of spent catalyst on rate and selectivity

S5. Formation of Pd-diacetate clusters as a deactivation mechanism

S6. Effect of $\mathrm{H}_{2} \mathrm{O}$ and $\mathrm{CH}_{3} \mathrm{CHO}$ pressure on rate

S7. Rate equation derivations, fitted parameters, parity plots and alternative models

S7.1 Model 1, Main Text

S7.2 Model 2, Main Text

S7.3 Modified Model 1 with $\beta$-hydride elimination

S7.4 Model 3, Main Text

S7.5 Modified Model 3 with acetates as H-abstractors

S7.6 Modified Models 1, 2, 3 with the inclusion of sequential reactions of OOH species

S7.7 Model 4: $\mathrm{O}-\mathrm{H}$ and $\mathrm{C}-\mathrm{H}$ activation using $\mathrm{O}$-atoms form dissociated $\mathrm{O}_{2}$

S7.8 Model 5: $\mathrm{C}$-H activation in $\mathrm{C}_{2} \mathrm{H}_{4}$ to from vinyl species (Moiseev pathway)

S7.9 Discussion on alternative models

S8. Measured CO pressure as a function of reactant pressure

S9. Effect of switching between labeled and unlabeled reactants on VA formation rate

S10. Enthalpy and entropy calculations

S11. DFT derived minimum energy path and barrier for acetate hopping

S12. AIMD calculations for determining stable adsorbate configurations

S13. Effect of acetate coverage on $\mathrm{CH}_{3} \mathrm{COOH}, \mathrm{O}_{2}, \mathrm{C}_{2} \mathrm{H}_{4}$ and $\mathrm{CO}$ adsorption energies and their van der Waals components

S14. DFT derived proton hopping steps and $\mathrm{O}-\mathrm{H}$ activation barriers

S15. Energies as a function of reaction coordinate for acetate formation, $\mathrm{O}_{2}$ dissociation and VA formation at $7 / 16$ coverage

S16. Effect of coverage on intrinsic $\mathrm{C}-\mathrm{O}$ coupling barriers

S17. Electronic energies, enthalpies, entropies and free energies of reactive intermediates and transition states

S18. Effect of calculation methods on electronic energies

S19. Effect of atom perturbation length on vibrational frequencies and thermodynamic

contributions 


\section{S1. TEM images of $1 \mathrm{wt} \% \% \mathrm{Pd} / \mathrm{SiO}_{2}$ before and after reaction}

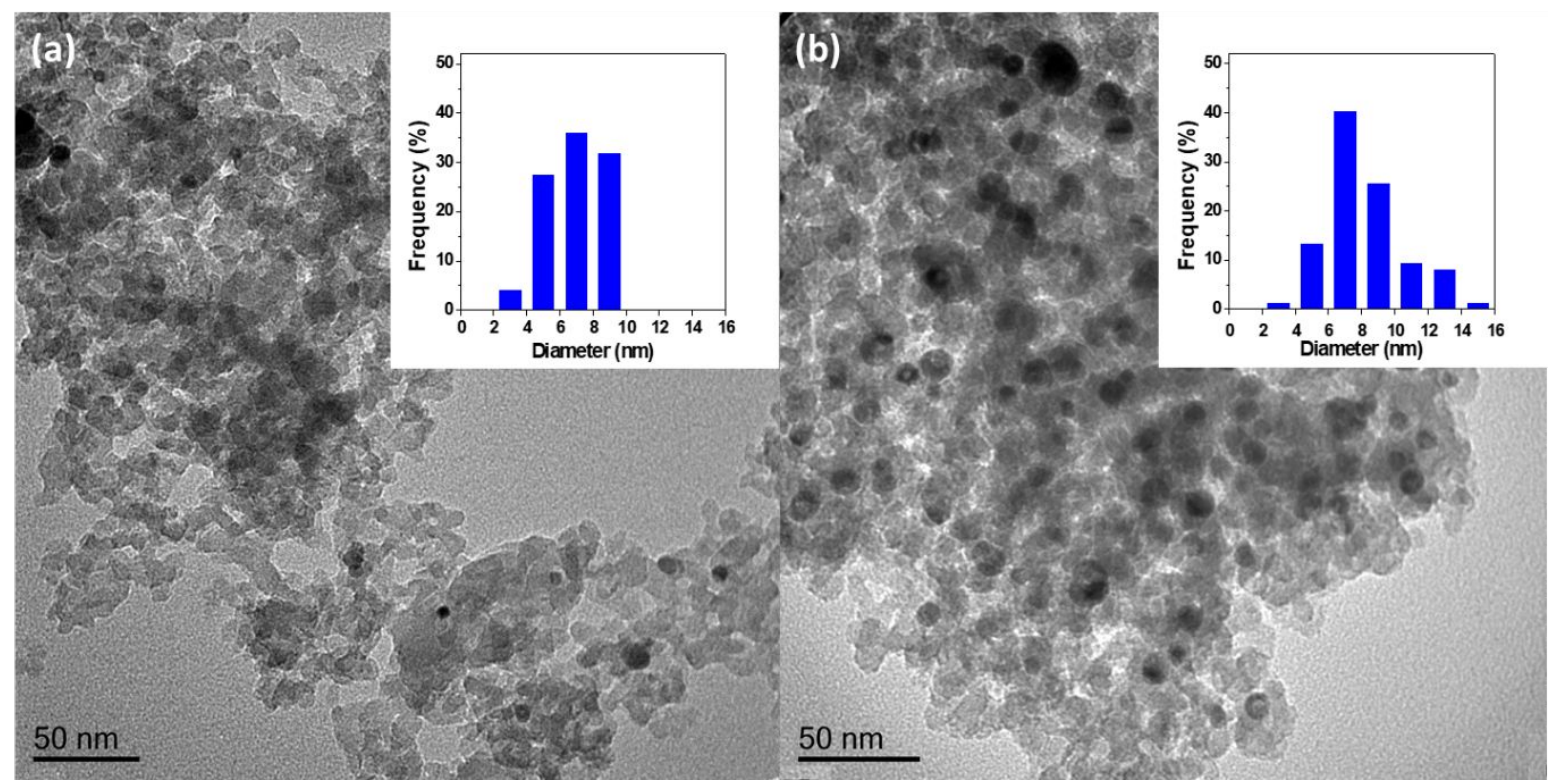

Figure S1. Micrograph of the (a) fresh $\mathrm{Pd} / \mathrm{SiO}_{2} 1 \mathrm{wt}$ \% sample and the same sample (b) after $4 \mathrm{~h}$ on stream $\left(433 \mathrm{~K}, 40 \mathrm{kPa} \mathrm{C}_{2} \mathrm{H}_{4}, 10 \mathrm{kPa} \mathrm{CH} \mathrm{COOH}_{3}, 5 \mathrm{kPa} \mathrm{O}_{2}, 40 \mathrm{~cm}^{3} \mathrm{~min}^{-1}\right)$. Both samples were reduced in $\mathrm{H}_{2}$ at $673 \mathrm{~K}$ for $2 \mathrm{~h}$ before observation. Insets show Pd particle size distributions. Average diameter: (a) $7.61 \mathrm{~nm}$ (b) $10.04 \mathrm{~nm}$. 


\section{S2. IR spectra for $1 \mathrm{wt.} \% \mathrm{Pd} / \mathrm{SiO}_{2}$ at reaction conditions}
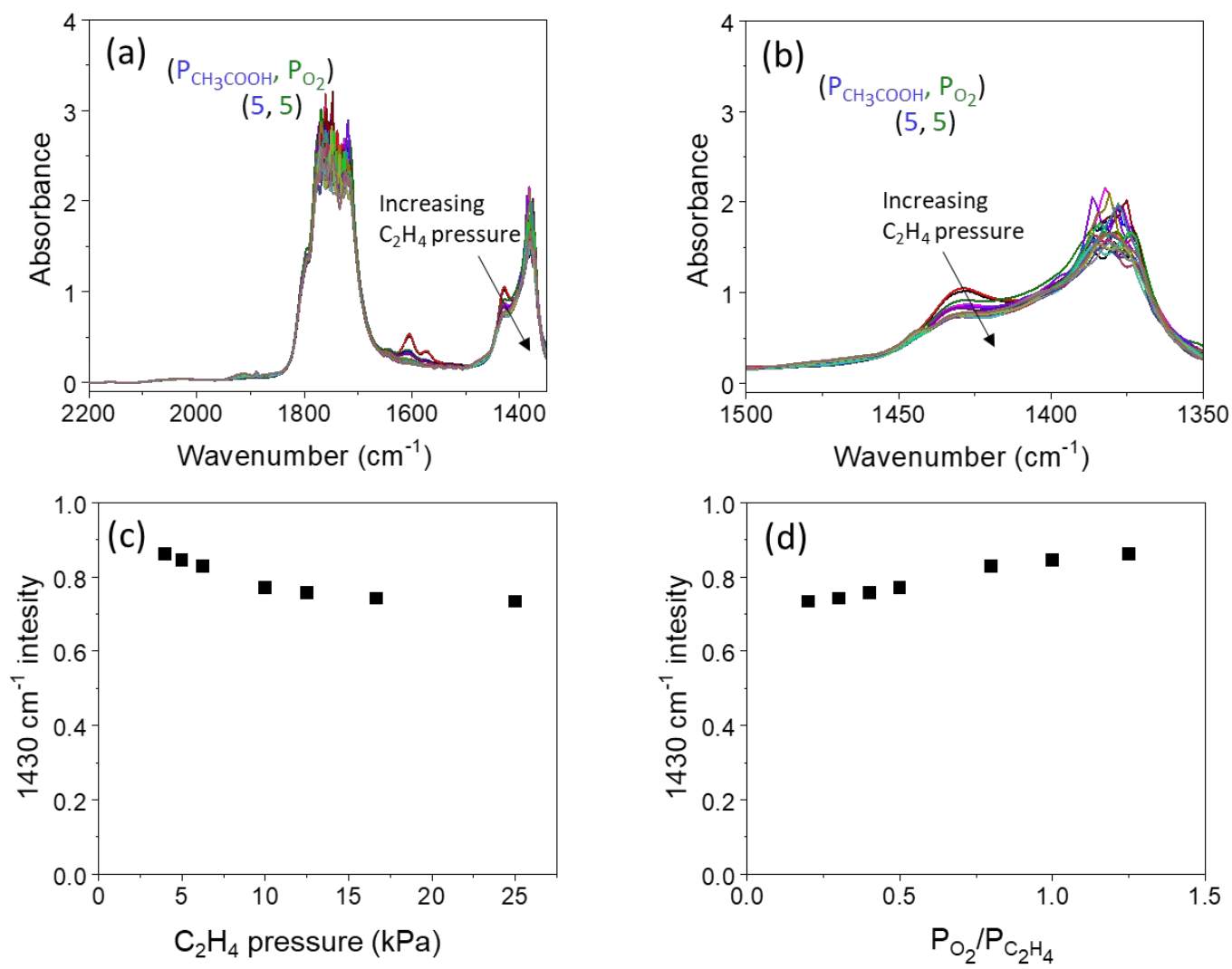

Figure S2. In situ transmission Fourier-transform infrared spectra of $1 \mathrm{wt} \% \mathrm{Pd} / \mathrm{SiO}_{2}$ in wavenumber range of (a) $2200-1350 \mathrm{~cm}^{-1}$ and (b) $1500-1350 \mathrm{~cm}^{-1}\left(423 \mathrm{~K}, 4-25 \mathrm{kPa} \mathrm{C}_{2} \mathrm{H}_{4} 5 \mathrm{kPa}\right.$ $\mathrm{CH}_{3} \mathrm{COOH}$ conv. $<5 \%, 10 \mathrm{kPa} \mathrm{O}_{2}$ ). (c) The intensity of the peak at $1430 \mathrm{~cm}^{-1}$ as a function of ethylene pressure and (d) the ratio of $\mathrm{O}_{2}$ pressure to $\mathrm{C}_{2} \mathrm{H}_{4}$ pressure. Methods in Main Text.

The intensity of the peak at $1430 \mathrm{~cm}^{-1}$ represent the surface concentration of acetate species. The surface concentrations of acetate species decrease with ethylene pressure, which is consistent with coverages predicted in kinetic models. 


\section{S3. Effect of size of catalyst aggregates on rate and selectivity}
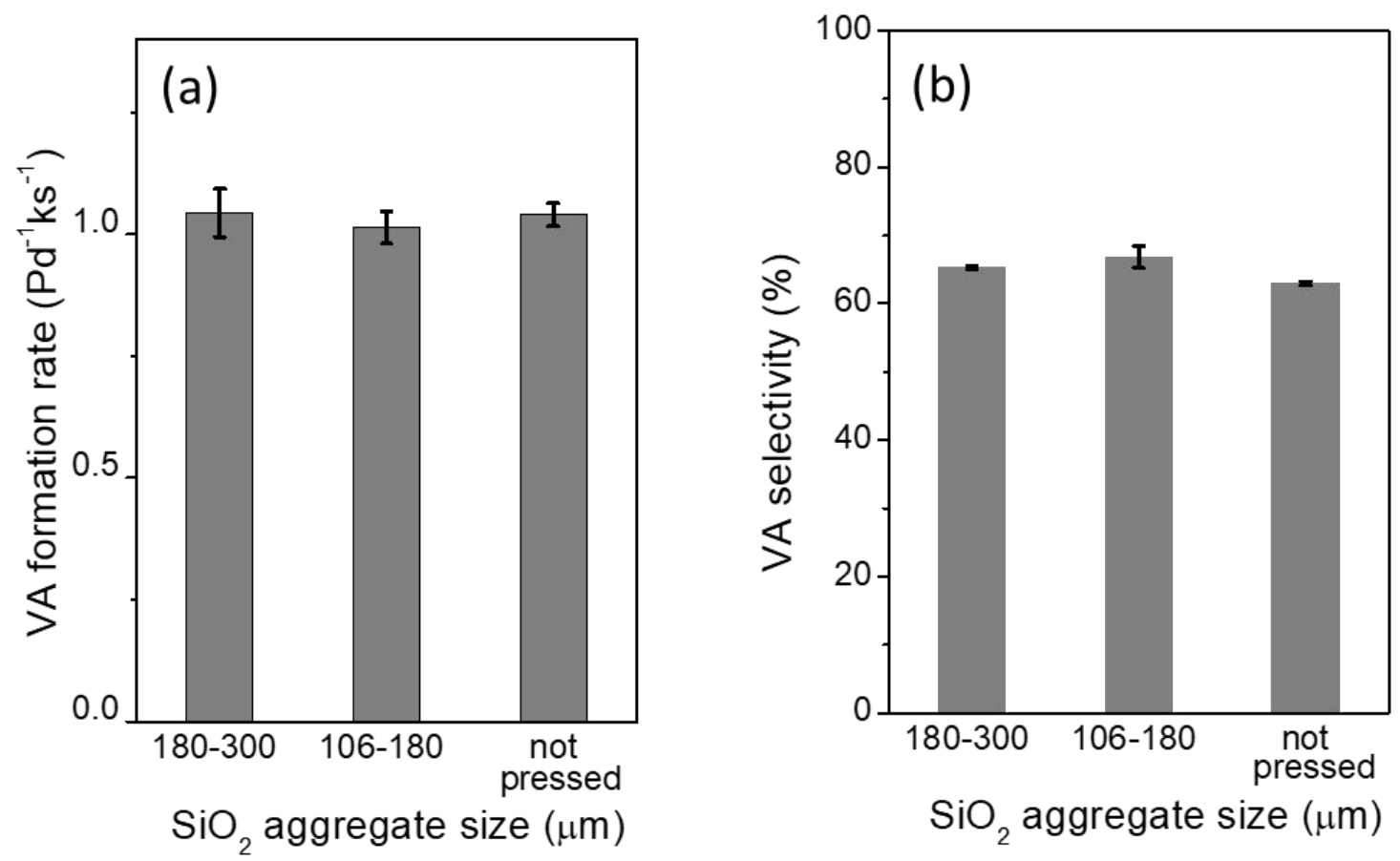

Figure S3. (a) VA formations rates and (b) VA selectivities $1 \% \mathrm{Pd} / \mathrm{SiO}_{2}$ samples of different $\mathrm{SiO}_{2}$ aggregate sizes $\left(433 \mathrm{~K}, 40 \mathrm{kPa} \mathrm{C}_{2} \mathrm{H}_{4}, 10 \mathrm{kPa} \mathrm{CH}_{3} \mathrm{COOH}, 5 \mathrm{kPa} \mathrm{O} 2,40 \mathrm{~cm}^{3} \mathrm{~min}^{-1}\right)$.

Rates and selectivities are independent of the aggregate sizes, which suggests that rates are limited by kinetics and internal transport limitations are absent. 
S4. Effect of $\mathbf{H}_{2}$ treatment of spent catalyst on rate and selectivity
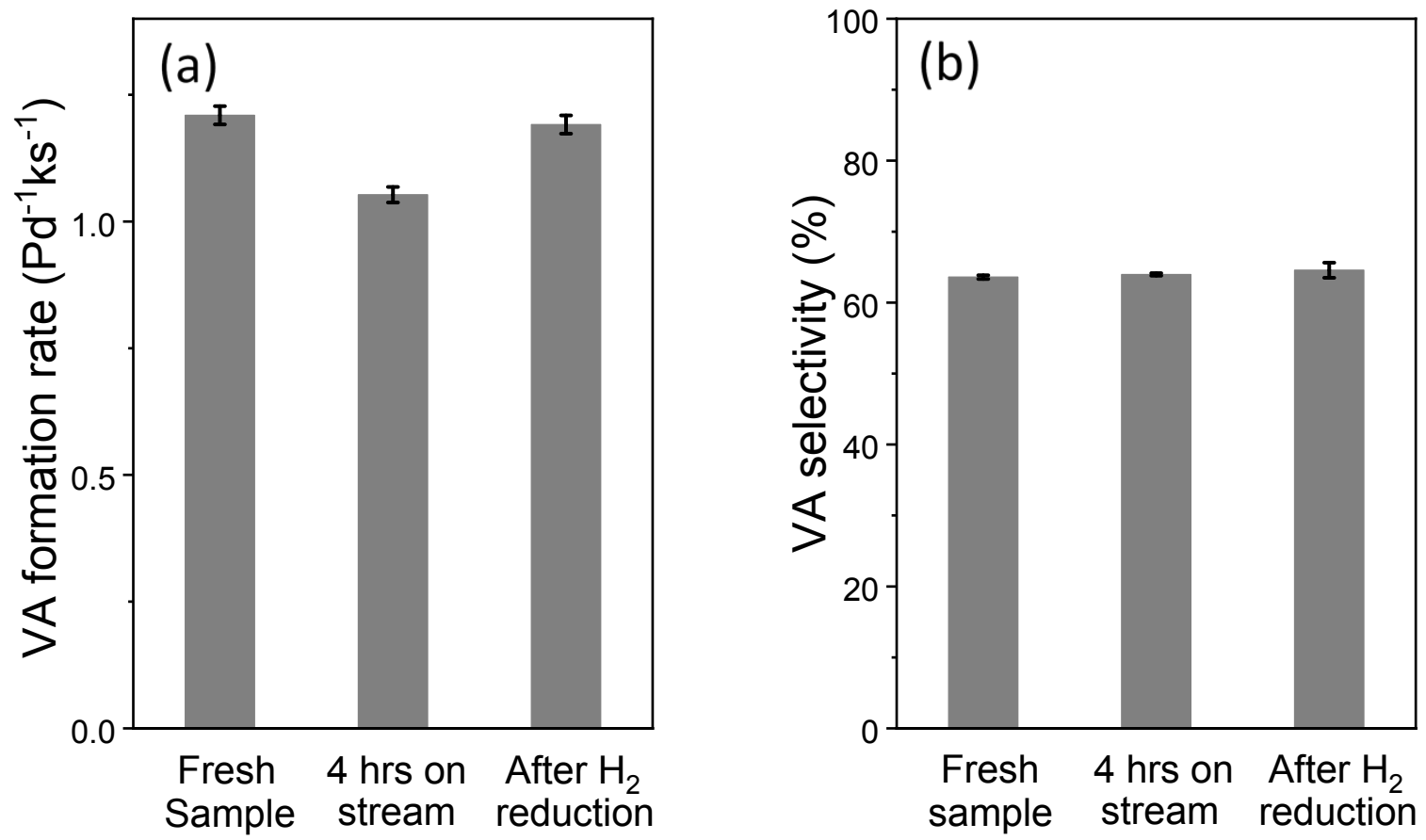

Figure S4. (a) VA rates and (b) selectivities on $1 \mathrm{wt} . \% \mathrm{Pd} / \mathrm{SiO}_{2}$ sample fresh, after exposure to reaction condition for $4 \mathrm{~h}\left(433 \mathrm{~K}, 40 \mathrm{kPa} \mathrm{C}_{2} \mathrm{H}_{4}, 10 \mathrm{kPa} \mathrm{CH} \mathrm{COOH}_{3} \mathrm{COPa} \mathrm{O}, 40 \mathrm{~cm}^{3} \mathrm{~min}^{-1}\right)$ and after post-reaction $\mathrm{H}_{2}$ treatment at $673 \mathrm{~K}$ for 30 min.

Rates are lower after four hours, consistent with the deactivation shown in Main Text, but activity is fully recovered after $\mathrm{H}_{2}$ treatment. 


\section{S5. Formation of Pd-diacetate clusters as a deactivation mechanism}

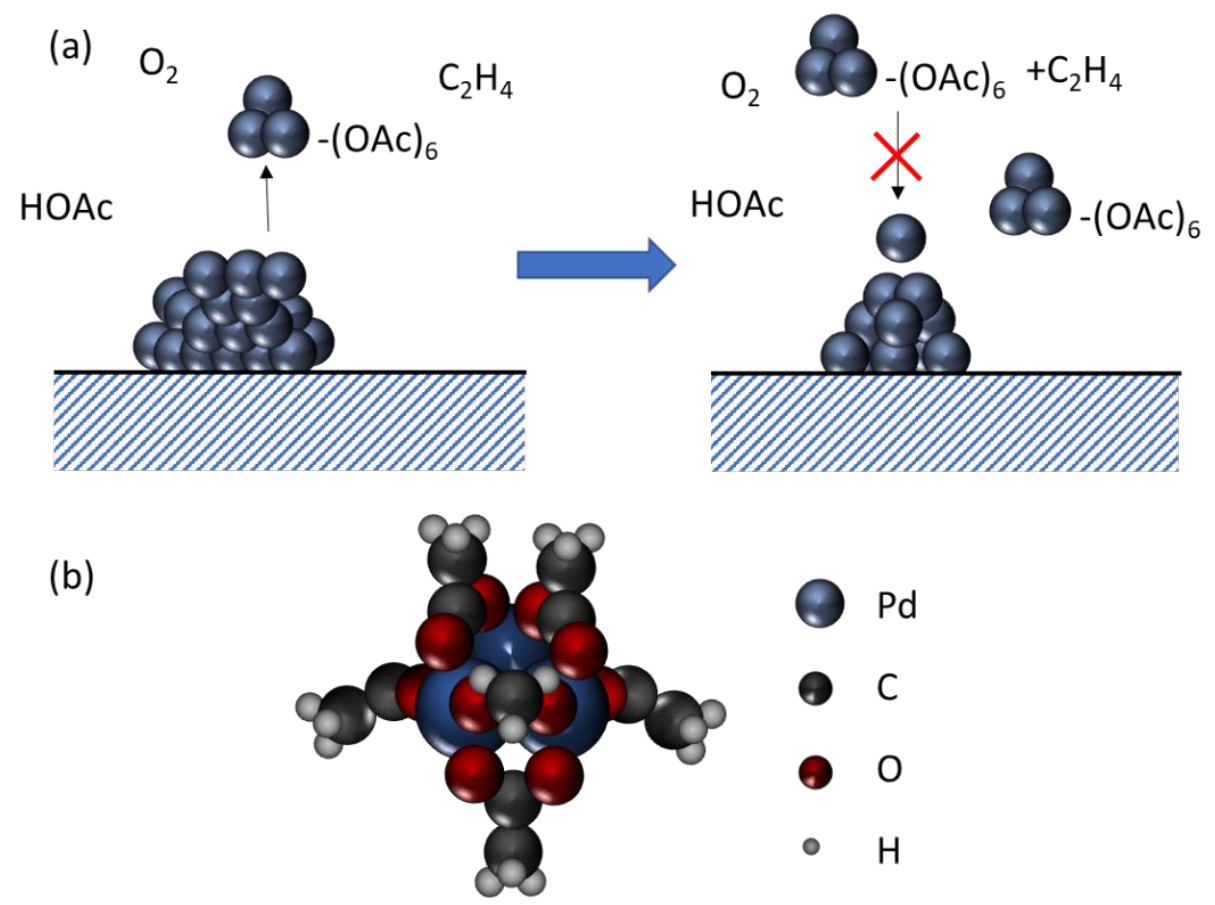

Figure S5. (a) A scheme showing the formation of inactive $\mathrm{Pd}$ (II) acetate trimer $\left(\mathrm{Pd}_{3}(\mathrm{OAc})_{6}\right)$, as a possible mode of the loss of Pd active sites with time on stream. (b) structure of a Pd (II) acetate trimer.

This mechanism was proposed by Lercher et al. ${ }^{\mathrm{S} 1} \mathrm{Pd}$ active sites are depleted by oxidative leaching that leads to the formation of inactive $\mathrm{Pd}_{3}(\mathrm{OAc})_{6}$ in the acetic acid layer. The reduction of $\mathrm{Pd}_{3}(\mathrm{OAc})_{6}$ with ethylene to reincorporate $\mathrm{Pd}^{0}$ into $\mathrm{Pd}$ particles is not facile unless alkali promoters are added. 
S6. Effect of $\mathrm{H}_{2} \mathrm{O}$ and $\mathrm{CH}_{3} \mathrm{CHO}$ pressure on rate
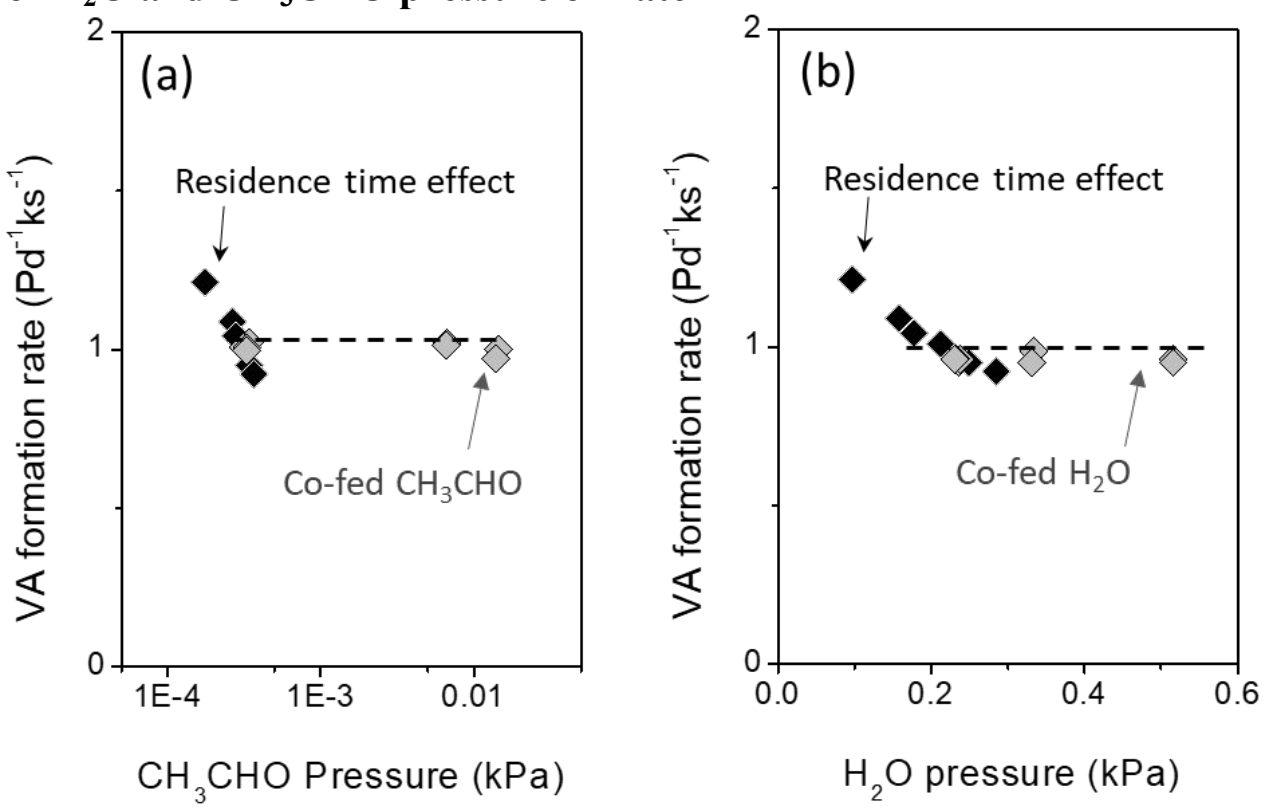

Figure S6. VA rate as a function of (a) average $\mathrm{CH}_{3} \mathrm{CHO}$ pressure and (b) average $\mathrm{H}_{2} \mathrm{O}$ pressure to compare residence time effects with co-fed products at fixed residence time on $1 \mathrm{wt} . \%$ $\mathrm{Pd} / \mathrm{SiO}_{2}\left(433 \mathrm{~K}, 40 \mathrm{kPa} \mathrm{C} \mathrm{H}_{4}, 10 \mathrm{kPa} \mathrm{CH} \mathrm{COOH}_{3}, 5 \mathrm{kPa} \mathrm{O}, \mathrm{C}_{2} \mathrm{H}_{4}\right.$ and $\mathrm{CH}_{3} \mathrm{COOH}$ conv. $<3 \%$, $\mathrm{O}_{2}$ conv. $\left.<9 \%\right)$. 


\section{S7. Rate equation derivations, fitted parameters and parity plots}

The rate equations are derived using elementary steps proposed in Scheme 3 (Main Text), and from alternative steps considered.

\section{S7.1 Model 1, Main Text:}

In Model 1 (Scheme 3), the $\mathrm{C}_{2} \mathrm{H}_{4}, \mathrm{CH}_{3} \mathrm{COOH}, \mathrm{CO}$ and $\mathrm{O}_{2}$ adsorptions and $\mathrm{C}-\mathrm{O}$ coupling are quasi-equilibrated, and acetate formation via $\mathrm{O}-\mathrm{H}$ activation and $\mathrm{VA}$ formation via $\mathrm{C}-\mathrm{H}$ bond activation are irreversible. Concentrations of all non-equilibrated surface intermediates ([I*]) is obtained by applying pseudo-steady-state hypothesis (PSSH),

$$
\frac{d\left[I^{*}\right]}{d t} \times \frac{1}{[L]} \cong 0
$$

where $[\mathrm{L}]$ is the total concentration of active sites.

Concentrations of equilibrated species (Steps 1-4, Main Text) are as following:

$$
\begin{gathered}
K_{1}=\frac{\left[\mathrm{C}_{2} \mathrm{H}_{4} *\right]}{P_{\mathrm{C}_{2} \mathrm{H}_{4}}[*]} \\
K_{2}=\frac{\left[\mathrm{CH}_{3} \mathrm{COOH}\right]}{P_{\mathrm{CH}_{3} \mathrm{COOH}}[*]} \\
K_{3}=\frac{[\mathrm{CO} *]}{P_{\mathrm{CO}[*]}\left[O^{*}\right.} \\
K_{4}=\frac{\left[\mathrm{O}_{2} *\right]}{P_{\mathrm{O}_{2}}[*]}
\end{gathered}
$$

The PSSH for the concentration of surface acetate is given by rates of its formation and consumption (Steps 5, 7, Scheme 3):

$$
\frac{d\left[\mathrm{CH}_{3} \mathrm{COO} *\right]}{d t}=k_{5}\left[\mathrm{CH}_{3} \mathrm{COOH} *\right] \frac{\left[\mathrm{O}_{2} *\right]}{[\mathrm{L}]}-k_{7}\left[\mathrm{CH}_{3} \mathrm{COOC}_{2} \mathrm{H}_{4} *\right] \frac{\left[\mathrm{O}_{2} *\right]}{[\mathrm{L}]} \cong 0
$$

The equilibrium between acetate and acetoxyethyl species (Step 6, Scheme 3) gives:

$$
\left[\mathrm{CH}_{3} \mathrm{COOC}_{2} \mathrm{H}_{4} *\right][*]=\mathrm{K}_{6}\left[\mathrm{CH}_{3} \mathrm{COO} *\right]\left[\mathrm{C}_{2} \mathrm{H}_{4} *\right]
$$

Re-arranging Equations S2-S7 gives surface concentrations of different species:

$$
\begin{aligned}
& {\left[\mathrm{C}_{2} \mathrm{H}_{4} *\right]=K_{1} P_{C_{2} H_{4}}[*]} \\
& {\left[\mathrm{CH}_{3} \mathrm{COOH} *\right]=\mathrm{K}_{2} \mathrm{P}_{\mathrm{CH}_{3} \mathrm{COOH}}[*] \quad(\mathrm{S} 9) \quad[\mathrm{CO} *]=K_{3} P_{\mathrm{CO}}[*]} \\
& \text { (S10) } \\
& {\left[\mathrm{O}_{2} *\right]=\mathrm{K}_{4} \mathrm{P}_{\mathrm{O}_{2}}[*]} \\
& {\left[\mathrm{CH}_{3} \mathrm{COOC}_{2} \mathrm{H}_{4} *\right]=\frac{k_{5}}{k_{7}} \mathrm{~K}_{2} \mathrm{P}_{\mathrm{CH}_{3} \mathrm{COOH}}[*]} \\
& {\left[\mathrm{CH}_{3} \mathrm{COO} *\right]=\frac{k_{5} \mathrm{~K}_{2} P_{\mathrm{CH}_{3} \mathrm{COOH}}}{k_{7} \mathrm{~K}_{6} \mathrm{~K}_{1} P_{\mathrm{C}_{2} \mathrm{H}_{4}}}[*]}
\end{aligned}
$$

The site balance is given by:

$[L]=[*]+\left[\mathrm{C}_{2} \mathrm{H}_{4} *\right]+\left[\mathrm{CH}_{3} \mathrm{COOH} *\right]+[\mathrm{CO} *]+\left[\mathrm{O}_{2} *\right]+\left[\mathrm{CH}_{3} \mathrm{COO} *\right]+$ $\left[\mathrm{CH}_{3} \mathrm{COOC}_{2} \mathrm{H}_{4} *\right]$

Equation S14 assumes that concentrations of $\mathrm{OOH}^{*}$ and other reactive oxygen species derived from its subsequent reactions is small because these highly reactive species when formed are quickly removed by proton transfers (Fig. S18 below) and reaction with organic molecules.

The VA formation rate $\left(\mathrm{r}_{\mathrm{VA}}\right)$ is given by the net forward rate of a non-equilibrated step, taken here as the irreversible $\mathrm{C}-\mathrm{H}$ activation step to form $\left[\mathrm{CH}_{3} \mathrm{COOC}_{2} \mathrm{H}_{3} *\right.$ ] (Step 7 in Scheme 3, Main Text):

$$
\frac{r_{V A}}{[L]}=k_{7} \frac{\left[\mathrm{CH}_{3} \mathrm{COOC}_{2} \mathrm{H}_{4} *\right]\left[\mathrm{O}_{2} *\right]}{\mathrm{S} 8}
$$


Substituting Equations S8-S14 into Equation S15 gives the VA formation rate expression,

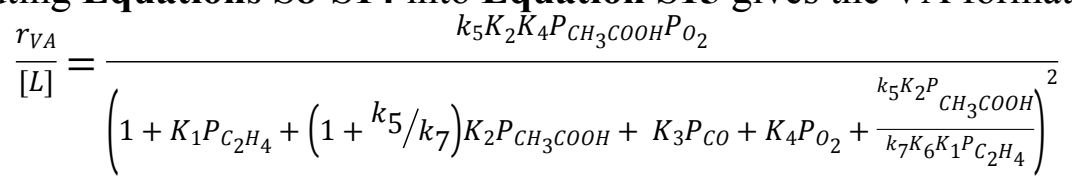

Based on the discussions in the Main Text, this equation can be simplified and rearranged for relevant conditions to the form of Equation 2.

Table S1. Rate and equilibrium constants derived from regression of rate data in Figure 3, Main Text to the form of Equation 2. The coefficient of determination $\left(R^{2}\right)$ is 0.80 . Uncertainties represent standard error.

\begin{tabular}{ccc}
\hline Parameter & Value & Units \\
\hline$k_{O-H}$ & $6.8( \pm 5.6) \times 10^{-4}$ & $\mathrm{Pd}^{-1} \mathrm{~s}^{-1} \mathrm{kPa}^{-2}$ \\
$K_{3}$ & $59.6( \pm 39.3)$ & $\mathrm{kPa}^{-1}$ \\
$K_{4}$ & $0.80( \pm 0.38)$ & $\mathrm{kPa}^{-1}$ \\
$k_{C-H}$ & $4.5( \pm 4.4) \times 10^{-3}$ & $\mathrm{Pd}^{-1} \mathrm{~s}^{-1} \mathrm{kPa}^{-1}$ \\
$k_{C-H} / k_{O-H}$ & $0.66( \pm 0.34)$ & $\mathrm{kPa}^{-1}$ \\
\hline
\end{tabular}

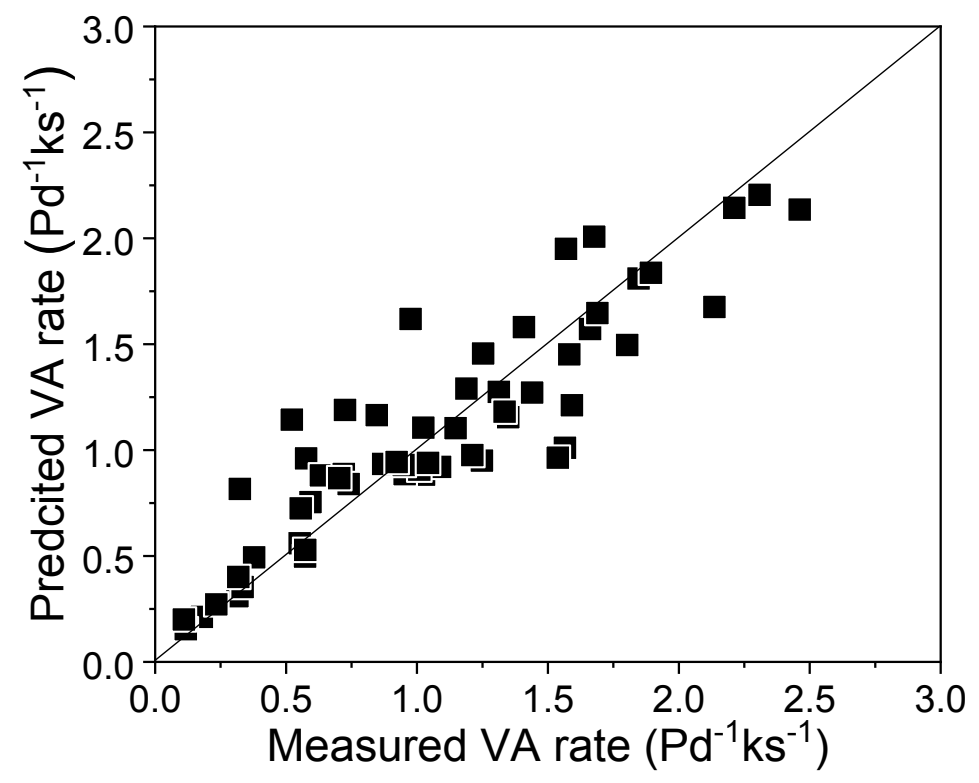

Figure S7. Parity plot comparing measured and predicted VA rates for Model 1.

\section{S7.2 Model 2, Main Text:}

In Model 2, the equilibrated Step 6 is replaced with an irreversible step (Step 6'). In this case, the $\mathrm{PSSH}$ for $\mathrm{CH}_{3} \mathrm{COO} *$ and $\mathrm{CH}_{3} \mathrm{COOC}_{2} \mathrm{H}_{4} *$ are given by:

$$
\begin{gathered}
\frac{d\left[\mathrm{CH}_{3} \mathrm{COO} *\right]}{d t}=k_{5}\left[\mathrm{CH}_{3} \mathrm{COOH} *\right] \frac{\left[\mathrm{O}_{2} *\right]}{[L]}-k_{6}\left[\mathrm{CH}_{3} \mathrm{COO} *\right] \frac{\left[\mathrm{C}_{2} \mathrm{H}_{4} *\right]}{[L]} \cong 0 \\
\frac{d\left[\mathrm{CH}_{3} \mathrm{COOC}_{2} \mathrm{H}_{4} *\right]}{d t}=k_{6}\left[\mathrm{CH}_{3} \mathrm{COO} *\right] \frac{\left[\mathrm{C}_{2} \mathrm{H}_{4} *\right]}{[L]}-k_{7}\left[\mathrm{CH}_{3} \mathrm{COOC}_{2} \mathrm{H}_{4} *\right] \frac{\left[\mathrm{O}_{2} *\right]}{[L]} \cong 0
\end{gathered}
$$


This, together with Equations S8-S11, gives:

$$
\begin{gathered}
{\left[\mathrm{CH}_{3} \mathrm{COOC}_{2} \mathrm{H}_{4} *\right]=\frac{k_{6}}{k_{7}} K_{2} P_{\mathrm{CH}_{3} \mathrm{COOH}}[*]} \\
{\left[\mathrm{CH}_{3} \mathrm{COO} *\right]=\frac{k_{5} K_{2} P_{\mathrm{CH}_{3} \mathrm{COOH}_{4} \mathrm{PO}_{2}}}{k_{6} \mathrm{~K}_{1} P_{C_{2} \mathrm{H}_{4}}}[*]}
\end{gathered}
$$

The concentrations in Equations S8-S11 and S19-S20 along with site balance (Eq. S14) and the forward rate for Step 7 (Eq. S15) gives the following rate equation for Model 2:

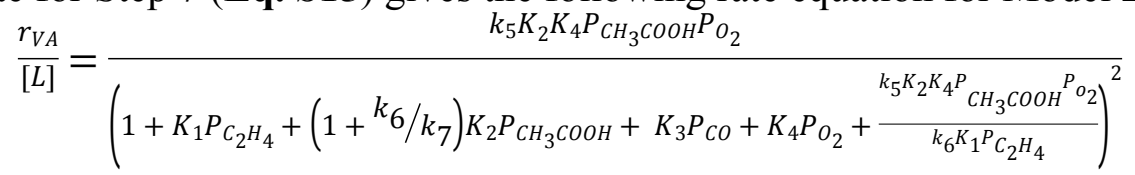

which can be simplified to Equation 5 in the Main Text for relevant conditions.

Table S2. Rate and equilibrium constants derived from regression of rate data in Figure 3, Main Text to the form of Equation 5. The coefficient of determination $\left(R^{2}\right)$ is 0.87 . Uncertainties represent standard error.

\begin{tabular}{ccc}
\hline Parameter & Value & Units \\
\hline$k_{O-H}$ & $1.9( \pm 0.5) \times 10^{-4}$ & $\mathrm{Pd}^{-1} \mathrm{~s}^{-1} \mathrm{kPa}^{-2}$ \\
$K_{3}$ & $32.7( \pm 8.7)$ & $\mathrm{kPa}^{-1}$ \\
$K_{4}$ & $0.31( \pm 0.06)$ & $\mathrm{kPa}^{-1}$ \\
$k_{\text {coupl }}$ & $2.4( \pm 0.8) \times 10^{-3}$ & $\mathrm{Pd}^{-1} \mathrm{~s}^{-1} \mathrm{kPa}^{-1}$ \\
$k_{O-H} / k_{\text {coupl }}$ & $0.08( \pm 0.02)$ & $\mathrm{kPa}^{-1}$ \\
\hline
\end{tabular}

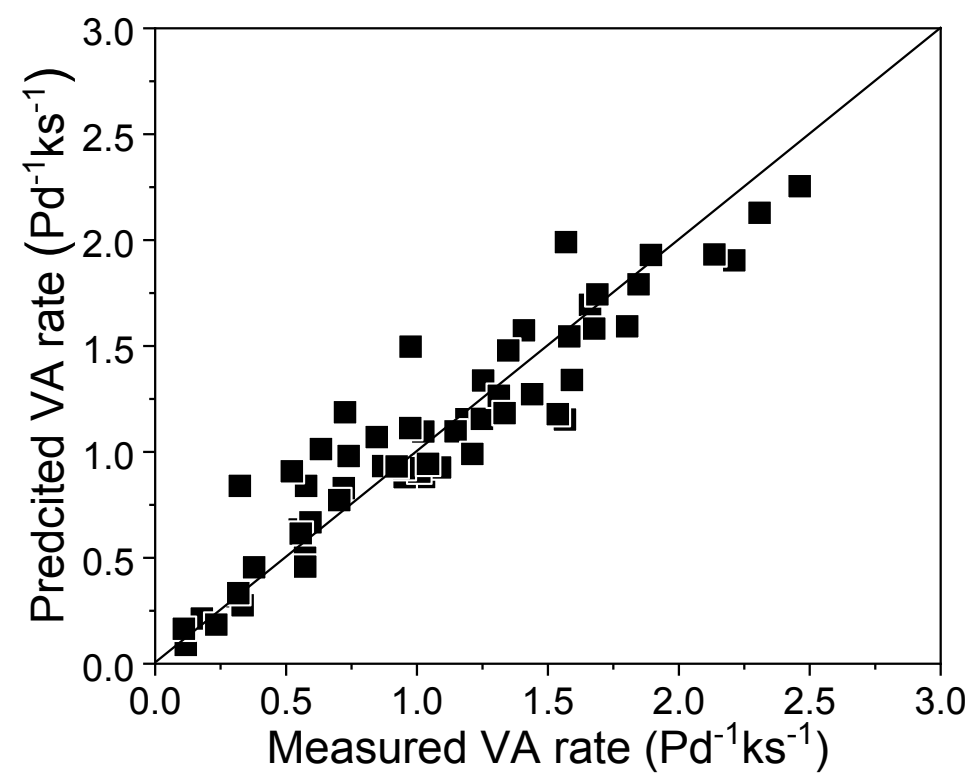

Figure S8. Parity plot comparing measured and predicted VA rates for Model 2. 


\section{S7.3 Modified Model 1 with $\beta$-hydride elimination:}

$$
\begin{array}{llll}
\mathrm{CH}_{3} \mathrm{COOH}^{*}+\mathrm{O}_{2}{ }^{*} & \stackrel{k_{5}}{\longrightarrow} \mathrm{CH}_{3} \mathrm{COO}^{*}+\mathrm{OOH}^{*} & \text { (5) } \\
\mathrm{CH}_{3} \mathrm{COO}^{*}+\mathrm{C}_{2} \mathrm{H}_{4}{ }^{*} \stackrel{\mathrm{K}_{7}}{\longrightarrow} \mathrm{CH}_{3} \mathrm{COOC}_{2} \mathrm{H}_{4}{ }^{*} & \mathrm{CH}_{3} \mathrm{COOC}_{2} \mathrm{H}_{3}{ }^{*}+\mathrm{H}^{*} & \text { (6) } \\
\mathrm{CH}_{3} \mathrm{COOC}_{2} \mathrm{H}_{4}{ }^{*}++^{*} \stackrel{\mathrm{C}^{\prime}}{\longrightarrow} & &
\end{array}
$$

Scheme S1. Proposed elementary steps involving $\mathrm{C}-\mathrm{H}$ activation via $\beta$-hydride elimination. Other steps are identical to Model 1 in Scheme 3 in Main Text.

The PSSH for the concentration of surface acetate is given by rates of its formation and consumption (Steps 5, 7', Scheme S1):

$$
\frac{d\left[\mathrm{CH}_{3} \mathrm{COO} *\right]}{d t}=k_{5}\left[\mathrm{CH}_{3} \mathrm{COOH} *\right] \frac{\left[O_{2} *\right]}{[L]}-k_{7}\left[\mathrm{CH}_{3} \mathrm{COOC}_{2} \mathrm{H}_{4} *\right] \frac{[*]}{[L]} \cong 0
$$

The equilibrium between acetate and acetoxyethyl species (Step 6, Scheme 3) gives:

$$
\left[\mathrm{CH}_{3} \mathrm{COOC}_{2} \mathrm{H}_{4} *\right][*]=\mathrm{K}_{6}\left[\mathrm{CH}_{3} \mathrm{COO} *\right]\left[\mathrm{C}_{2} \mathrm{H}_{4} *\right]
$$

Re-arranging Equations S22-S23 gives surface concentrations of different species:

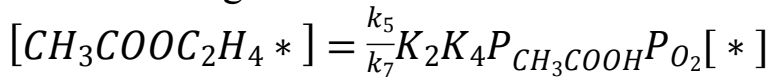

$$
\begin{aligned}
& {\left[\mathrm{CH}_{3} \mathrm{COO} *\right]=\frac{k_{5} \mathrm{~K}_{2} \mathrm{~K}_{4} \mathrm{P}_{\mathrm{CH}_{3} \mathrm{COOH}_{\mathrm{H}} \mathrm{O}_{2}}}{k_{7} \mathrm{~K}_{6} \mathrm{~K}_{1} P_{C_{2} \mathrm{H}_{4}}}[*]}
\end{aligned}
$$

Substituting Equations S8-S11 and S24-S25 into Equation S15 gives the VA formation rate expression,

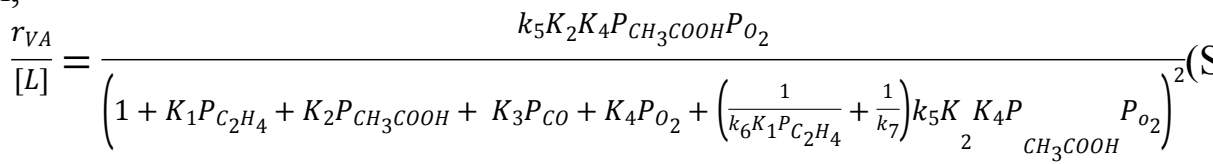

which can be also simplified to Equation 5 in Main Text for relevant conditions, and the fitting results are shown in Table $\mathbf{S 2}$ and Figure $\mathbf{S 8 .}$

\section{S7.4 Model 3, Main Text:}

Model 3 (Scheme 4, Main Text) adds Step 9 to Model 2, which involves acetate oxidation $\mathrm{O}_{2}$. In this case the PSSH for $\mathrm{CH}_{3} \mathrm{COO}^{*}$ becomes:

$$
\frac{d\left[\mathrm{CH}_{3} \mathrm{COO} *\right]}{d t}=k_{5}\left[\mathrm{CH}_{3} \mathrm{COOH} *\right] \frac{\left[\mathrm{O}_{2} *\right]}{[L]}-k_{6}\left[\mathrm{CH}_{3} \mathrm{COO} *\right] \frac{\left[\mathrm{C}_{2} \mathrm{H}_{4} *\right]}{[L]}-k_{9}\left[\mathrm{CH}_{3} \mathrm{COO} *\right] \frac{\left[\mathrm{O}_{2} *\right]}{[L]} \cong 0
$$

This, together with Equations S8-S11 and S18, gives:

$$
\begin{gathered}
{\left[\mathrm{CH}_{3} \mathrm{COOC}_{2} \mathrm{H}_{4} *\right]=\frac{k_{6}}{k_{7}} K_{2} P_{\mathrm{CH}_{3} \mathrm{COOH}}[*]} \\
{\left[\mathrm{CH}_{3} \mathrm{COO} *\right]=\frac{k_{5} K_{2} P_{\mathrm{CH}_{3} \mathrm{COOH}} K_{4} P_{O_{2}}}{k_{6} K_{1} P_{C_{2} \mathrm{H}_{4}}+k_{9} K_{4} P_{O_{2}}}[*]}
\end{gathered}
$$

The concentrations in Equations S8-S11 and S28-S29 along with site balance (Eq. S14) and the forward rate for Step 7 (Eq. S15) gives the following rate equation for Model 3: 


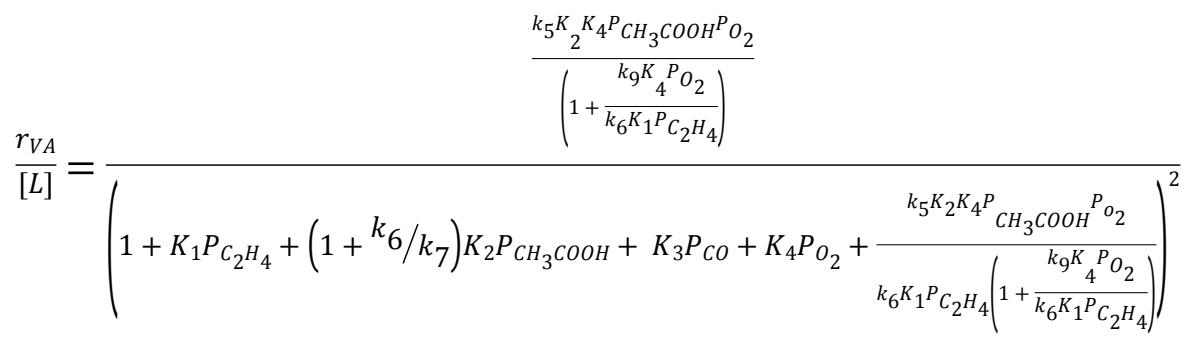

which can be simplified to Equation 9 in Main Text for relevant conditions.

Rate and equilibrium constants derived from regression of rate data in Figure 3 to the form of Equation 9 are shown in Table 1, Main Text. The coefficient of determination $\left(\mathrm{R}^{2}\right)$ is 0.92 .

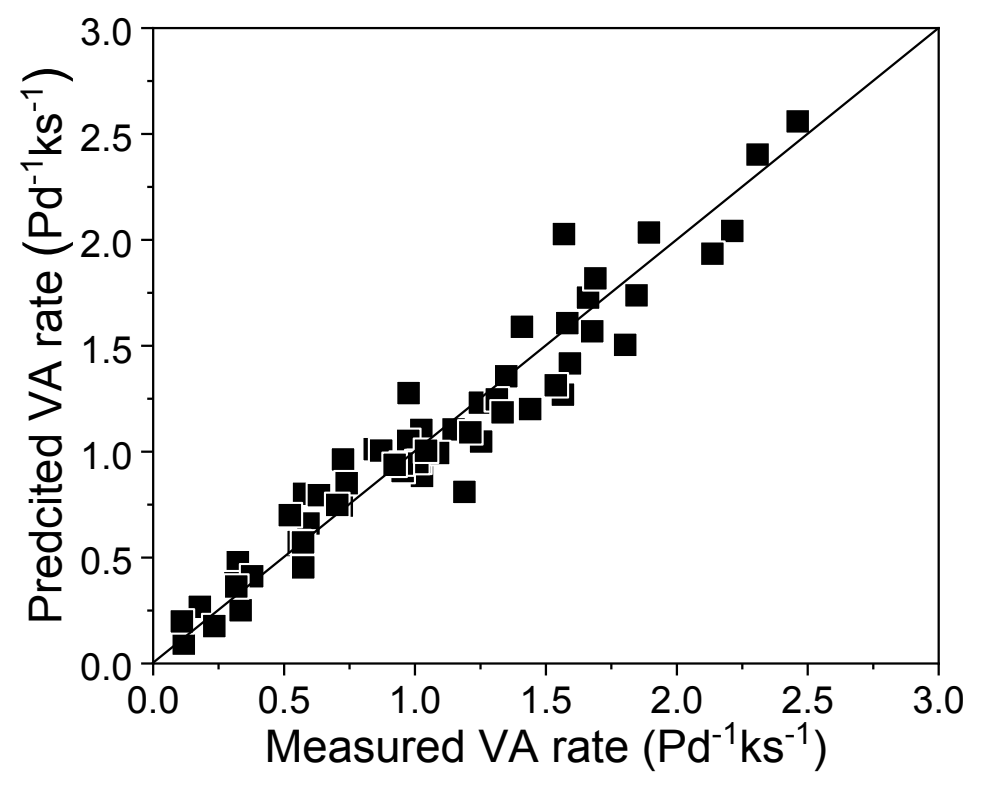

Figure S9. Parity plot comparing measured and predicted VA rates for Model 3.

\section{S7.5 Modified Model 3 with acetates as H-abstractors:}

$$
\begin{array}{rlll}
\mathrm{CH}_{3} \mathrm{COO}^{*}+\mathrm{C}_{2} \mathrm{H}_{4}{ }^{*} & \stackrel{k_{6}}{\longrightarrow} & \mathrm{CH}_{3} \mathrm{COOC}_{2} \mathrm{H}_{4}{ }^{* *} \\
\mathrm{CH}_{3} \mathrm{COOC}_{2} \mathrm{H}_{4}{ }^{*}+\mathrm{CH}_{3} \mathrm{COO}^{*} & \stackrel{k_{7}}{\longrightarrow} & \mathrm{CH}_{3} \mathrm{COOC}_{2} \mathrm{H}_{3}{ }^{*}+\mathrm{CH}_{3} \mathrm{COOOH}^{*} \\
\left.\mathrm{CH}_{3} \mathrm{COO}^{*}+\mathrm{O}_{2}{ }^{*}\right) & \stackrel{k_{9}}{\longrightarrow} & \mathrm{CH}_{3} \mathrm{OO}^{*}+\mathrm{CO}_{2}{ }^{*}
\end{array}
$$

Scheme S2. Proposed elementary steps involving $\mathrm{C}-\mathrm{H}$ activation with $\mathrm{CH}_{3} \mathrm{COO} *$ as the abstractor. Other steps are identical to Scheme 3 in Main Text.

Scheme S2 shows a modified version of Model 3 in which acetate species abstracts $\mathrm{H}$ atoms instead of $\mathrm{O}_{2}$. In this case, the PSSH for $\mathrm{CH}_{3} \mathrm{COO}^{*}$ becomes:

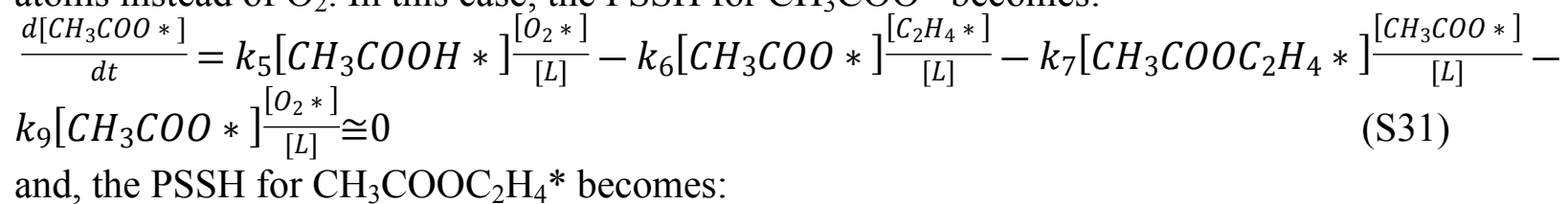




$$
\frac{d\left[\mathrm{CH}_{3} \mathrm{COOC}_{2} \mathrm{H}_{4} *\right]}{d t}=k_{6}\left[\mathrm{CH}_{3} \mathrm{COO} *\right] \frac{\left[\mathrm{C}_{2} \mathrm{H}_{4} *\right]}{[L]}-k_{7}\left[\mathrm{CH}_{3} \mathrm{COOC}_{2} \mathrm{H}_{4} *\right] \frac{\left[\mathrm{CH}_{3} \mathrm{COO} *\right]}{[\mathrm{L}]} \cong 0
$$

This, together with Equations S8-S11 gives:

$$
\begin{gathered}
{\left[\mathrm{CH}_{3} \mathrm{COOC}_{2} \mathrm{H}_{4} *\right]=\frac{k_{6}}{k_{7}} K_{1} P_{C_{2} \mathrm{H}_{4}}[*]} \\
{\left[\mathrm{CH}_{3} \mathrm{COO} *\right]=\frac{k_{5} K_{2} P_{\mathrm{CH}_{3} \mathrm{COOH}} K_{4} P_{O_{2}}}{2 k_{6} \mathrm{~K}_{1} P_{C_{2} \mathrm{H}_{4}}+k_{9} K_{4} P_{O_{2}}}[*]}
\end{gathered}
$$

The concentrations in Equations S8-S11 and S33-S34 along with site balance (Eq. S14) and the forward rate for Step 7 (Eq. S15) gives the following rate equation for Model 3:

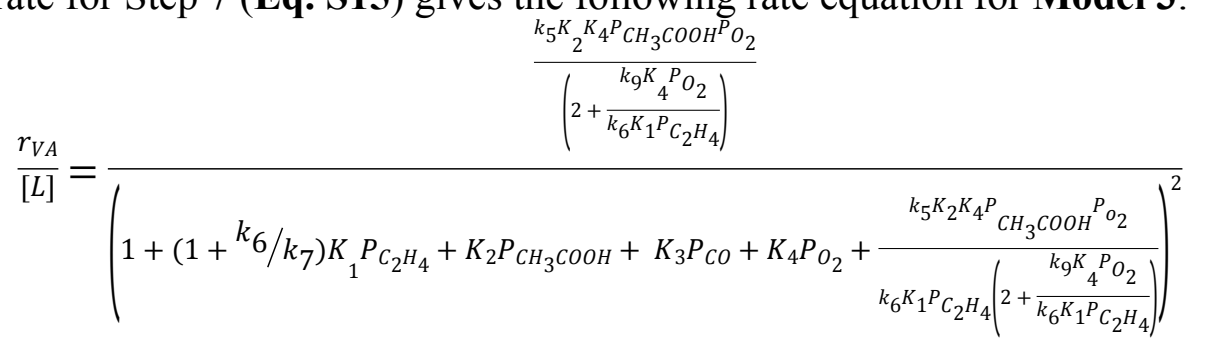

Equation S35 has the same general functional form as $\mathbf{S 3 0}$ (except that $k_{6}$ becomes $2 k_{6}$ ), which dictates that this model gives the same fit at Model 3.

\section{S7.6 Modified Models 1, 2,3 with the inclusion of sequential reactions of OOH species:}

Hydroperoxo species may be rapidly consumed by additional transfer of $\mathrm{H}$-atoms to form $\mathrm{H}_{2} \mathrm{O}$. Step 8 in Scheme 3 in Main Text shows multiple plausible rapid steps in a lumped form (Step 8 in Scheme 3). Alternatively, the hydroperoxo species can be directly involved in oxidizing other molecules. ${ }^{\mathrm{S} 2}$ For VA synthesis such steps can involve $\mathrm{O}-\mathrm{H}$ and $\mathrm{C}-\mathrm{H}$ activations that are considered in Scheme 3 to only occur via $\mathrm{O}_{2}$. Here, Scheme $\mathbf{S 3}$ considers the additional sequential steps involving $\mathrm{C}-\mathrm{H}$ and $\mathrm{O}-\mathrm{H}$ activations by $\mathrm{OOH}, \mathrm{OH}$ and $\mathrm{O}$ species.

$$
\begin{aligned}
& \mathrm{CH}_{3} \mathrm{COOH}^{*}+\mathrm{O}_{2}^{*} \stackrel{k_{5}}{\longrightarrow} \mathrm{CH}_{3} \mathrm{COO}^{*}+\mathrm{OOH}^{*} \\
& \mathrm{CH}_{3} \mathrm{COOH}^{*}+\mathrm{OOH}^{*} \stackrel{k_{5,1}}{\longrightarrow} \mathrm{CH}_{3} \mathrm{COO}^{*}+\mathrm{O}^{*}+\mathrm{H}_{2} \mathrm{O} \quad(5,1) \\
& \mathrm{CH}_{3} \mathrm{COOH}^{*}+\mathrm{O}^{*} \stackrel{k_{5,2}}{\longrightarrow} \mathrm{CH}_{3} \mathrm{COO}^{*}+\mathrm{OH}^{*} \quad(5,2) \\
& \mathrm{CH}_{3} \mathrm{COOH}^{*}+\mathrm{OH}^{*} \stackrel{k_{5,3}}{\longrightarrow} \mathrm{CH}_{3} \mathrm{COO}^{*}+*+\mathrm{H}_{2} \mathrm{O} \quad(5,3) \\
& \mathrm{CH}_{3} \mathrm{COOC}_{2} \mathrm{H}_{4}{ }^{*}+\mathrm{O}_{2}{ }^{*} \stackrel{k_{7}}{\longrightarrow} \mathrm{CH}_{3} \mathrm{COOC}_{2} \mathrm{H}_{3}{ }^{*}+\mathrm{OOH}^{*} \text { (7) } \\
& \mathrm{CH}_{3} \mathrm{COOC}_{2} \mathrm{H}_{4}{ }^{*}+\mathrm{OOH}^{*} \stackrel{k_{7,1}}{\longrightarrow} \mathrm{CH}_{3} \mathrm{COOC}_{2} \mathrm{H}_{3}+\mathrm{O}^{*}+\mathrm{H}_{2} \mathrm{O}(7,1) \\
& \mathrm{CH}_{3} \mathrm{COOC}_{2} \mathrm{H}_{4}{ }^{*}+\mathrm{O}^{*} \stackrel{k_{7,2}}{\longrightarrow} \mathrm{CH}_{3} \mathrm{COOC}_{2} \mathrm{H}_{3}+^{*}+\mathrm{OH}^{*} \quad(7,2) \\
& \mathrm{CH}_{3} \mathrm{COOC}_{2} \mathrm{H}_{4}{ }^{*}+\mathrm{OH}^{*} \stackrel{k_{7,3}}{\longrightarrow} \mathrm{CH}_{3} \mathrm{COOC}_{2} \mathrm{H}_{3}+*+\mathrm{H}_{2} \mathrm{O} \quad(7,3)
\end{aligned}
$$

Scheme S3. Proposed elementary steps for O-H and C-H activation by $\mathrm{OOH}, \mathrm{O}$ and $\mathrm{OH}$ species. Other steps are identical to Models 1, 2 or 3 in Main Text.

The derivation here was simplified a bit by assuming that activations by $\mathrm{O}^{*}$ and $\mathrm{OH}^{*}$ occur in a similar way as $\mathrm{OOH}^{*}$, but more rapidly than even $\mathrm{OOH}^{*}$ due to more reactive $\mathrm{O}^{*}$ and $\mathrm{OH}^{*}$. This leads to zero PSSH concentration of $\mathrm{O}^{*}$ and $\mathrm{OH}^{*}$. Thus, any activation by $\mathrm{OOH}^{*}$ will lead to 
two more activation, and their rates were added in a single term, as shown for the following equation for O-H activation in $\mathrm{CH}_{3} \mathrm{COOH}$ (Steps 5,1-5,3, Scheme S3):

$$
\left[\mathrm{CH}_{3} \mathrm{COOH} *\right]\left(k_{5,1}[\mathrm{OOH} *]+k_{5,2}[\mathrm{O} *]+k_{5,3}[\mathrm{OH} *]\right)=3 k_{5,1}\left[\mathrm{CH}_{3} \mathrm{COOH} *\right][\mathrm{OOH} *]
$$

And the following equation for $\mathrm{C}-\mathrm{H}$ activation in actoxyethyl species (Steps 7,1-7,3, Scheme S3):

$$
\left[\mathrm{CH}_{3} \mathrm{COOC}_{2} \mathrm{H}_{4} *\right]\left(k_{7,1}[\mathrm{OOH} *]+k_{7,2}[\mathrm{O} *]+k_{7,3}[\mathrm{OH} *]\right)=3 k_{7,1}\left[\mathrm{CH}_{3} \mathrm{COOC}_{2} \mathrm{H}_{4} *\right][\mathrm{OOH} *]
$$

Further derivation using this model requires $\mathrm{PSSH}$ on $\mathrm{OOH}^{*}$ species in addition to the additional terms in the PSSH for $\mathrm{CH}_{3} \mathrm{COO}^{*}$ and $\mathrm{CH}_{3} \mathrm{COOC}_{2} \mathrm{H}_{4}{ }^{*}$ considered in models above. The VA formation rate $\left(\mathrm{r}_{\mathrm{VA}}\right)$ is given by total rate of $\mathrm{C}-\mathrm{H}$ activation in acetoxyethyl (Steps 7-7,3 in Scheme S3):

$$
\frac{r_{V A}}{[L]}=k_{7}\left[\mathrm{CH}_{3} \mathrm{COOC}_{2} \mathrm{H}_{4} *\right]\left[\mathrm{O}_{2} *\right] \frac{1}{[L]^{2}}+3 k_{7,1}\left[\mathrm{CH}_{3} \mathrm{COOC}_{2} \mathrm{H}_{4} *\right][\mathrm{OOH} *] \frac{1}{[L]^{2}}
$$

Which, together with the concentrations form PSSH and quasi-equilibrium assumptions described above gives the following rate equation for Model 1:

$$
\frac{r_{V A}}{[L]}=\frac{\left(k_{5}+3 k^{\prime} k_{5,1}\right) K_{2} K_{4} P_{C_{3} \mathrm{COOH} P_{O_{2}}}}{\left(1+K_{1} P_{C_{2} \mathrm{H}_{4}}+\left(1+k^{\prime \prime}\right) K_{2} P_{\mathrm{CH}_{3} \mathrm{COOH}}+K_{3} P_{\mathrm{CO}}+K_{4}\left(1+k^{\prime}\right) P_{O_{2}}+\frac{k^{\prime \prime} K_{2} P_{C H} \mathrm{COOH}}{K_{1} P^{P} C_{2} H_{4}}\right)^{2}}
$$

Where $k^{\prime}={ }^{k_{5}} /\left(2 * k_{5} k_{5,1} k_{7,1} / k_{7}\left(k_{5}-k_{5,1}\right)-k_{5,1}\right)$ and $k^{\prime \prime}=k_{5} k_{5,1} / K_{6} K_{6,1} k_{7}\left(k_{5}-k_{5,1}\right)$

For Model 2, the above details lead to the following Equation:

$$
\begin{gathered}
\frac{r_{V A}}{[L]}=\frac{\left(2 k_{5}+2 k^{\prime \prime} k_{7}\right) K_{2} K_{4} P_{\mathrm{CH}_{3} \mathrm{COOH} P_{O_{2}}}}{\left(1+K_{1} P_{C_{2} H_{4}}+\left(1+k^{\prime \prime}\right) K_{2} P_{C_{3} \mathrm{COOH}}+K_{3} P_{\mathrm{CO}}+K_{4}\left(1+k^{\prime}\right) P_{O_{2}}+\frac{2 k_{5}+2 k^{\prime \prime} k_{7}}{k_{6}} \cdot \frac{{ }_{2} K_{4}{ }^{P} \mathrm{CH}_{3} \mathrm{COOH}^{P} O_{2}}{K_{1} P_{C_{2} H_{4}}}\right)^{2}}(\mathrm{~S} 40) \\
\text { Where } k^{\prime}=\left(k_{5}+4 k_{5} k_{7} /\left(k_{5} k_{7,1} / k_{5,1}\right)\right) / 3 k_{5,1} \text { and } k^{\prime \prime}={ }^{2 k_{5}} /\left(k_{5} k_{7,1} / k_{5,1}-k_{7}\right)
\end{gathered}
$$

Using Model 3, the VA formation rate expression is as follows:

$$
\begin{gathered}
\frac{r_{V A}}{[L]}=\frac{k_{6} K_{1} P_{c_{2} H_{4}} \frac{\left[{ }^{\left[H_{3} \mathrm{COO} *\right]}\right.}{[*]}}{\left(1+K_{1} P_{C_{2} H_{4}}+K_{2}\left(1+k^{\prime}\right) P_{C_{3} \mathrm{COOH}}+K_{3} P_{C O}+\left(1+k^{\prime}\right) K_{4} P_{O_{2}}+\frac{\left[\mathrm{CH}_{3} \mathrm{COO} *\right]}{[*]}\right)^{2}} \\
\left(\frac{\left[C \mathrm{CH}_{3} \mathrm{COO} *\right]}{[*]}=\frac{4 k_{5} K_{2} P_{\mathrm{CH}_{3} \mathrm{COOH}} K_{4} P_{O_{2}}}{k_{6} K_{1} P_{C_{2} \mathrm{H}_{4}}+k_{9} K_{4} P_{O_{2}}}\right)^{2}
\end{gathered}
$$

Where $k^{\prime}=k_{5} / k_{5,1}$ and $k^{\prime \prime}={ }^{k_{5}} /\left(3 k_{5} k_{7,1} / k_{5,1}+k_{7}\right)$

These derivations show that incorporating sequential steps leads to Equations (S39, S40, S41) that are of same functional form as the original Models 1, 2 and 3 (Eq. S16, S21, S30). The only difference is that the modified equations have parameters that have more rate constants lumped together. Thus, the same form indicates that the involvement of $\mathrm{OOH}$ species will not have any effect on kinetic behavior and cannot be discerned by fitting data to rate equations. 
S7.7 Model 4: $\mathrm{O}-\mathrm{H}$ and $\mathrm{C}-\mathrm{H}$ activation using $\mathrm{O}$-atoms from dissociated $\mathrm{O}_{2}:$ In an alternative route, $\mathrm{O}_{2}{ }^{*}$ species dissociate into $\mathrm{O}^{*}$ in a quasi-equilibrated step. The $\mathrm{O}-\mathrm{H}$ and $\mathrm{C}-\mathrm{H}$ activations to form and consume acetates occur using $\mathrm{O}^{*}$ instead of $\mathrm{O}_{2}{ }^{*}$. Such steps are shown in Scheme S4.

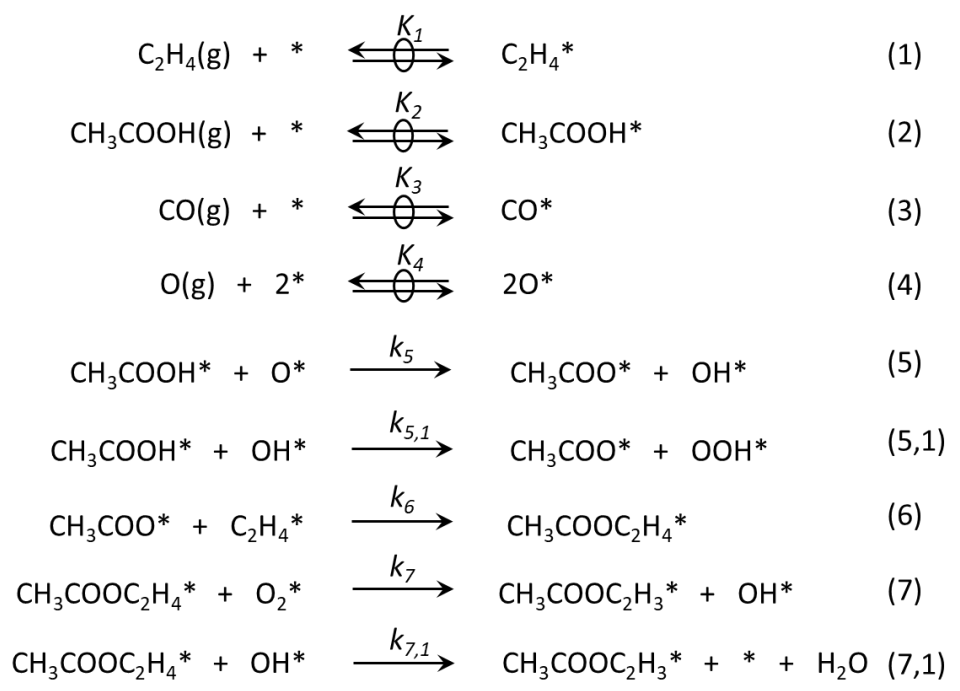

Scheme S4. Proposed elementary steps for VA formation via dissociated $\mathrm{O}^{*}$ species as $\mathrm{H}-$ abstractors.

The steps shown in Scheme $\mathbf{S 4}$ give the following rate equation:

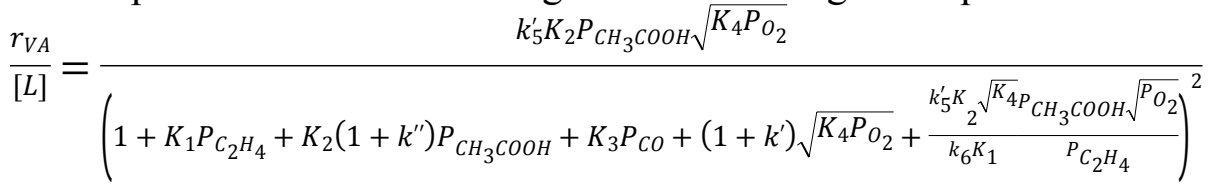

Where $k^{\prime}=\sqrt{\frac{k_{5} k_{7}}{k_{5,1} k_{7,1}}}, k^{\prime \prime}=\sqrt{\frac{k_{5} k_{5,1}}{k_{7} k_{7,1}}}$ and $k_{5}^{\prime}=k_{5}+k^{\prime} k_{5,1}=k_{5}+k_{5,1} \sqrt{k_{5} k_{7} / k_{5,1} k_{7,1}}$

Table S3. Rate and equilibrium constants derived from regression of rate data in Figure 3 (at $433 \mathrm{~K}$ ) to the form of Equation $\mathbf{S 4 2}$ with coefficient of determination $\mathrm{R}^{2}=0.80$. In $k_{O-H}, K_{4}$ was replaced by $\sqrt{K_{4}}$. Uncertainties represent standard error.

\begin{tabular}{ccc}
\hline Parameter & Value & Units \\
\hline$k_{O-H}$ & $4.7( \pm 3.0) \times 10^{-4}$ & $\mathrm{Pd}^{-1} \mathrm{~s}^{-1} \mathrm{kPa}^{-3 / 2}$ \\
$K_{3}$ & $35.4( \pm 16.7)$ & $\mathrm{kPa}^{-1}$ \\
$\sqrt{K_{4}}$ & $0.81( \pm 0.07)$ & $\mathrm{kPa}^{-1 / 2}$ \\
$k_{\text {coupl }}$ & $2.5( \pm 1.9) \times 10^{-3}$ & $\mathrm{Pd}^{-1} \mathrm{~s}^{-1} \mathrm{kPa}^{-1}$ \\
$k_{O-H} / k_{\text {coupl }}$ & $0.18( \pm 0.07)$ & $\mathrm{kPa}^{-1 / 2}$ \\
\hline
\end{tabular}




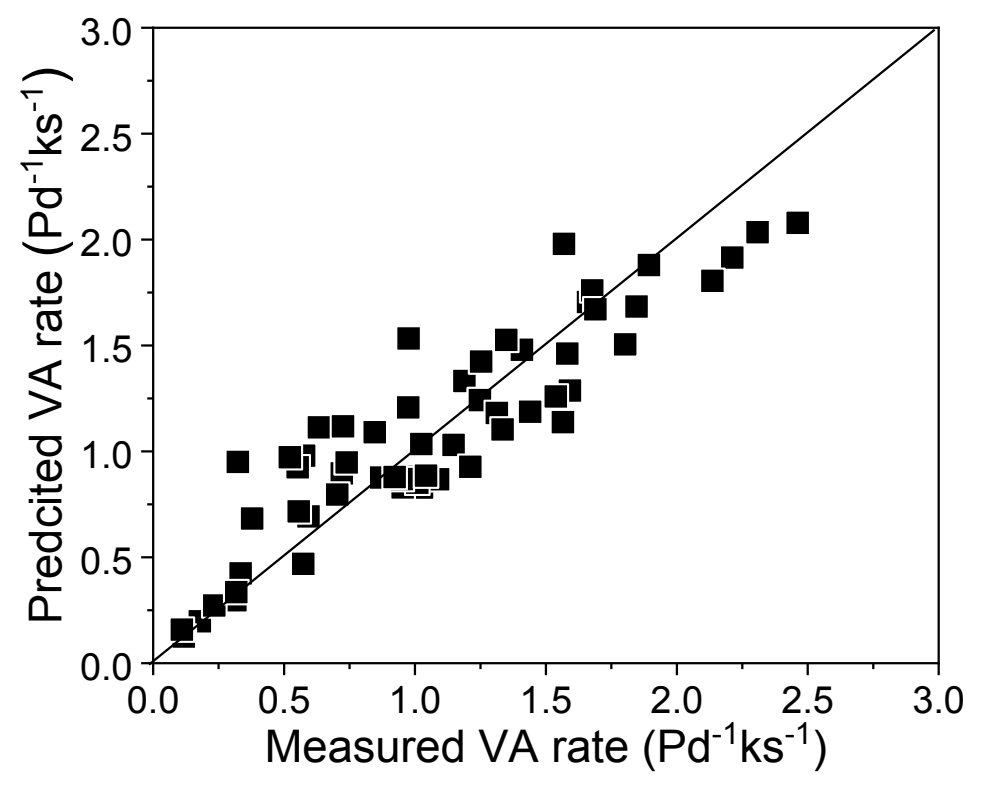

Figure S10. Parity plot comparing measured and predicted VA rates for Model 4.

S7.8 Model 5: $C-H$ activation in $C_{2} \underline{H}_{4}$ to form vinyl species (Moiseev pathway):

In yet another mechanism, ethylene activation to form vinyl species prior to coupling with acetates, we name it as Model 5. The elementary steps for this model are shown in Scheme S5.

$$
\begin{aligned}
& \mathrm{C}_{2} \mathrm{H}_{4}(\mathrm{~g})+* \stackrel{K_{1}}{\Longleftrightarrow} \mathrm{C}_{2} \mathrm{H}_{4}{ }^{*} \\
& \mathrm{CH}_{3} \mathrm{COOH}(\mathrm{g})+* \stackrel{K_{2}}{=} \mathrm{CH}_{3} \mathrm{COOH}^{*} \\
& \mathrm{CO}(\mathrm{g})+* \stackrel{K_{3}}{\stackrel{\mathrm{O}}{\longrightarrow}} \mathrm{CO} * \\
& \mathrm{O}_{2}(\mathrm{~g})+* \stackrel{K_{4}}{\stackrel{\leftrightarrow}{\leftrightarrows}} \mathrm{O}_{2}{ }^{*} \\
& \mathrm{CH}_{3} \mathrm{COOH}^{*}+\mathrm{O}_{2}{ }^{*} \stackrel{K_{5}}{\Longleftrightarrow} \mathrm{CH}_{3} \mathrm{COO}^{*}+\mathrm{OOH}^{*} \\
& \mathrm{CH}_{3} \mathrm{COOH}^{*}+\mathrm{OOH}^{*} \stackrel{K_{5,1}}{\longleftarrow} \mathrm{CH}_{3} \mathrm{COO}^{*}+{ }^{*}+\mathrm{H}_{2} \mathrm{O}(5,1) \\
& \mathrm{CH}_{3} \mathrm{COOH}^{*}+\mathrm{O}^{*} \stackrel{K_{5,2}}{\leftrightarrows} \mathrm{CH}_{3} \mathrm{COO}^{*}+\mathrm{OH}^{*} \quad(5,2) \\
& \mathrm{CH}_{3} \mathrm{COOH}^{*}+\mathrm{OH}^{*} \stackrel{K_{5,3}}{\longleftarrow} \mathrm{CH}_{3} \mathrm{COO}^{*}+\mathrm{OOH}^{*} \quad(5,3) \\
& \mathrm{C}_{2} \mathrm{H}_{4}{ }^{*}+\mathrm{O}_{2}{ }^{*} \stackrel{k_{6}}{\longrightarrow} \mathrm{C}_{2} \mathrm{H}_{3}{ }^{*}+\mathrm{OOH}^{*} \\
& \mathrm{C}_{2} \mathrm{H}_{4}{ }^{*}+\mathrm{OOH}^{*} \stackrel{k_{6,1}}{\longrightarrow} \mathrm{C}_{2} \mathrm{H}_{3}{ }^{*}+{ }^{*}+\mathrm{H}_{2} \mathrm{O} \quad(6,1) \\
& \mathrm{C}_{2} \mathrm{H}_{4}{ }^{*}+\mathrm{O}_{2}{ }^{*} \stackrel{k_{6,2}}{\longrightarrow} \mathrm{C}_{2} \mathrm{H}_{3}{ }^{*}+\mathrm{OH}^{*} \quad(6,2) \\
& \mathrm{C}_{2} \mathrm{H}_{4}{ }^{*}+\mathrm{OOH}^{*} \stackrel{k_{6,3}}{\longrightarrow} \mathrm{C}_{2} \mathrm{H}_{3}{ }^{*}+{ }^{*}+\mathrm{H}_{2} \mathrm{O} \quad(6,3) \\
& \mathrm{CH}_{3} \mathrm{COO}^{*}+\mathrm{C}_{2} \mathrm{H}_{3}{ }^{*} \stackrel{\mathrm{K}_{7}}{\longrightarrow} \mathrm{CH}_{3} \mathrm{COOC}_{2} \mathrm{H}_{3}{ }^{*} \\
& \mathrm{CH}_{3} \mathrm{COOH}^{*}+\mathrm{O}_{2}{ }^{*} \stackrel{k_{8}}{\longrightarrow} \mathrm{CH}_{3} \mathrm{OO}^{*}+\mathrm{CO}_{2}{ }^{*}
\end{aligned}
$$


Scheme S5. Proposed elementary steps for VA formation on $\mathrm{Pd} / \mathrm{SiO}_{2}$ based on Moiseev pathway.

These elementary steps lead to the following rate equation:

$$
\frac{r_{V A}}{[L]}=\frac{4 k_{6} K_{1} K_{4} P_{C_{2} H_{4}} P_{O_{2}}}{\left(1+K_{1} P_{C_{2} H_{4}}+\left(1+K_{5} \frac{k_{6,1}}{k_{6}}\right) K_{2} P_{C H_{3} \mathrm{COOH}}+K_{3} P_{C O}+K_{4}\left(1+\frac{k_{6,1}}{k_{6}}\right) P_{O_{2}}+\frac{4 k_{6}^{2}}{k_{5} k_{6,1} k_{7}} \cdot \frac{K_{1} K_{4} P_{C_{2} H_{4}{ }^{P} O_{2}}}{K_{2} P_{C H_{3} \mathrm{COOH}}}\right)^{2}}
$$

Table S4. Rate and equilibrium constants derived from regression of rate data in Figure 3 (at $433 \mathrm{~K}$ ) to the form of Equation $\mathbf{S 4 3}$ with coefficient of determination $\mathrm{R}^{2}=0.69$. Uncertainties represent standard error.

\begin{tabular}{ccc}
\hline Parameter & Value & Units \\
\hline $4 k_{6} K_{1} K_{4}$ & $8.3( \pm 5.8) \times 10^{-4}$ & $\mathrm{Pd}^{-1} \mathrm{~s}^{-1} \mathrm{kPa}^{-2}$ \\
$K_{3}$ & $113.1( \pm 52.1)$ & $\mathrm{kPa}^{-1}$ \\
$K_{4}$ & $0.60( \pm 0.28)$ & $\mathrm{kPa}^{-1}$ \\
$4 k_{6}^{2} K_{1} / K_{2} K_{4} K_{5} k_{6,1} k_{7}$ & $0.36( \pm 0.12)$ & $\mathrm{kPa}^{-1}$ \\
\hline
\end{tabular}

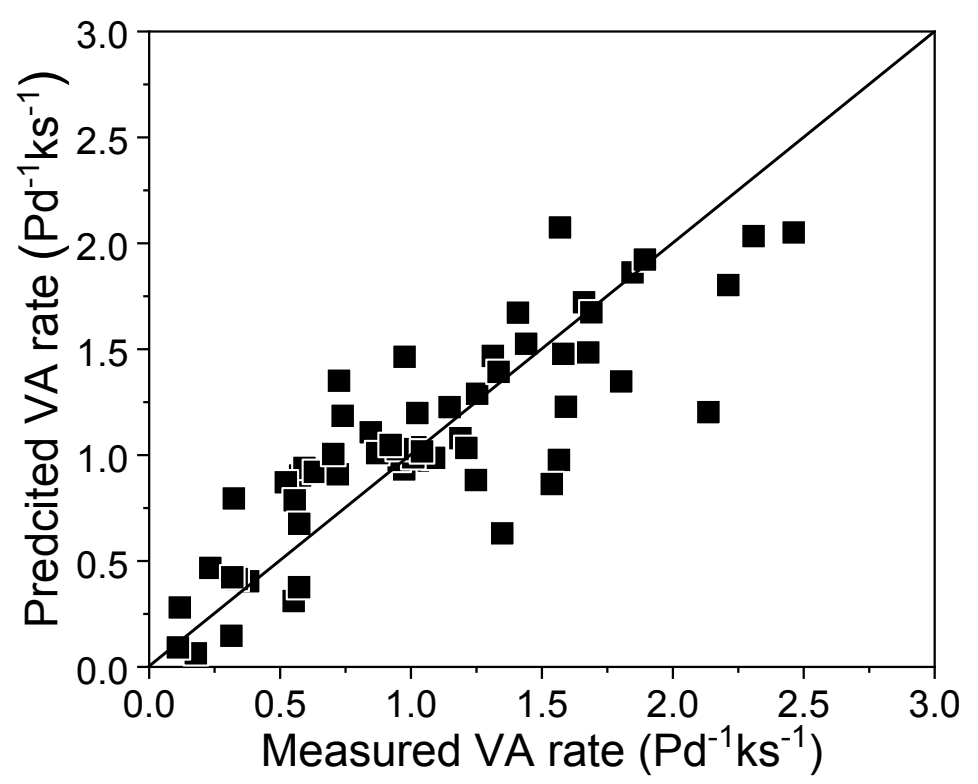

Figure S11. Parity plot comparing measured and predicted VA rates for Model 5.

\section{S7.9 Discussion on alternative models}

Steps 5 and 7 in Scheme 3 in Main Text consider C-H and O-H activations from $\mathrm{O}_{2}$ * instead of dissociated $\mathrm{O}^{*}$ species, based on our DFT calculations of $\mathrm{O}_{2}$ dissociation barriers (Figs. 6 and 7) and past studies suggesting that $\mathrm{O}_{2}$ mediated mechanisms prevail at high coverages. ${ }^{\mathrm{S} 3-6}$ The generation of $\mathrm{OOH}^{*}$ species via protonation of $\mathrm{O}_{2}$ on metal surfaces has been well studied. ${ }^{\mathrm{S} 7-9}$ The $\mathrm{OOH}^{*}$ species formed in these steps are typically much more reactive than $\mathrm{O}_{2}$ and can consumed rapidly. Such species can become significantly abundant on metals at conditions that do not dissociate $\mathrm{O}_{2}$, especially when large amounts of $\mathrm{H}_{2} \mathrm{O}$ or $\mathrm{H}_{2} \mathrm{O}_{2}$ is present and are known to 
have significant consequences for oxidation reactions such as alkene epoxidation or $\mathrm{CO}$ oxidation. ${ }^{\mathrm{S} 2}$, S7, S10-11 In this work, however, only a small amount of water is present, no epoxidation products are detected and increase in $\mathrm{H}_{2} \mathrm{O}$ pressure at higher conversion did not change the selectivity. Thus, $\mathrm{OOH}^{*}$ consumption was considered to be rapid. Step 8 lumps together possible proton transfer steps that form $\mathrm{H}_{2} \mathrm{O}$ from $\mathrm{OOH}^{*}$. Calculations in Section S14 below show that such proton transfer steps exhibit low barriers and are facile. Alternative steps involving activation of $\mathrm{CH}_{3} \mathrm{COOH}^{*}$ and $\mathrm{CH}_{3} \mathrm{COOC}_{2} \mathrm{H}_{4} *$ by $\mathrm{OOH}^{*}, \mathrm{O}^{*}$ and $\mathrm{OH}^{*}$ (analogous to Steps 5 and 7, but with stronger $\mathrm{H}$-abstractors than $\mathrm{O}_{2}{ }^{*}$ ) were also considered and shown to give same functional form rate equations (but with rate constants combined together in parameters that replace $k_{5}$ and $k_{7}$ ) as those resulting from steps in Scheme $\mathbf{3}$ as long as the concentration of the highly reactive oxygen species is small (Section S7.6 above). Alternative possibilities involving (i) $\mathrm{O}_{2}$ dissociation to $\mathrm{O}^{*}$, and (ii) ethylene activation to form vinyl species prior to coupling with acetates (Moiseev pathway ${ }^{\mathrm{S12}}$ ) were also considered and found to not describe the measured data well (SI, Section S7.7-S7.8). 
S8. Measured CO pressure as a function of reactant pressure
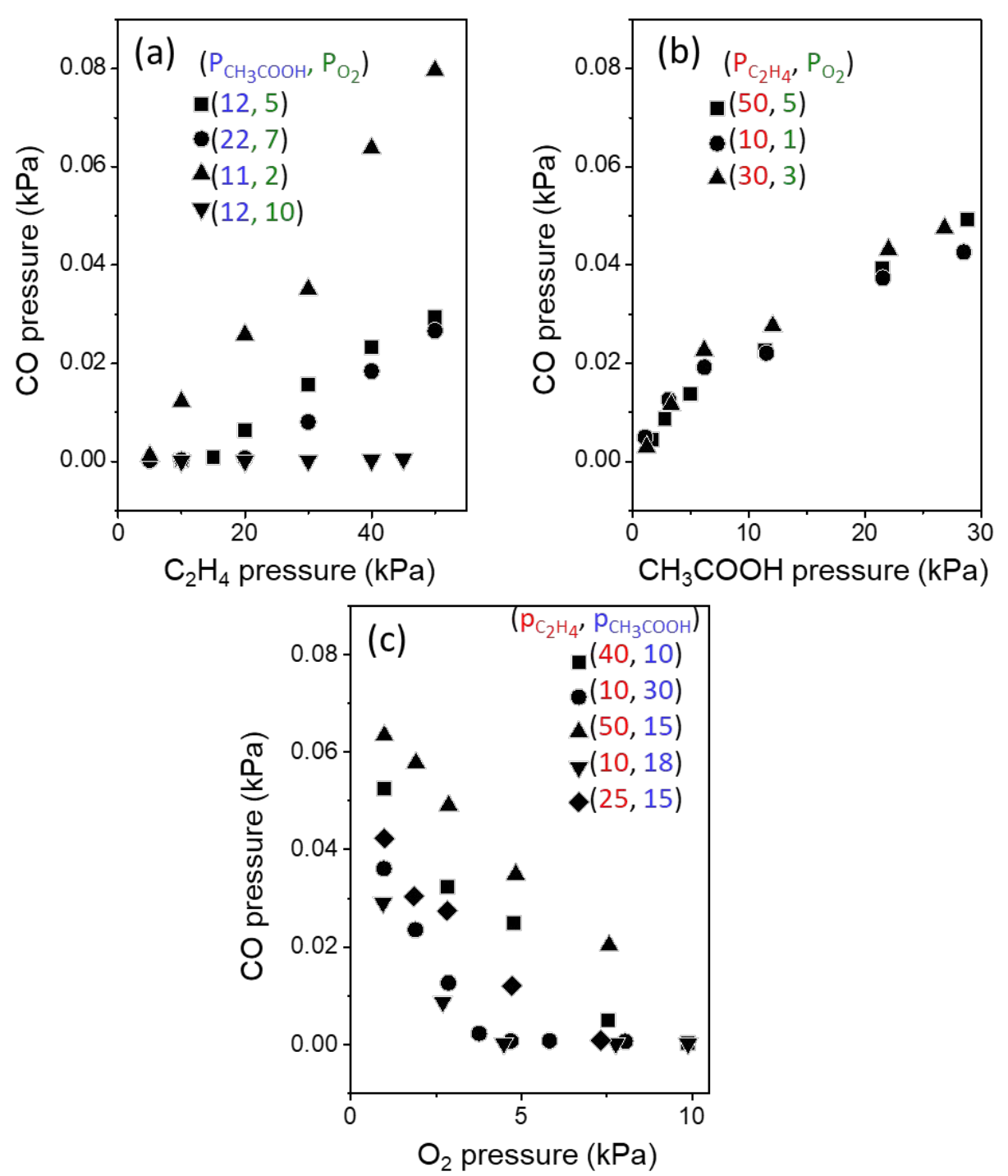

Figure S12. Measured $\mathrm{CO}$ pressure as a function of (a) $\mathrm{C}_{2} \mathrm{H}_{4}$, (b) $\mathrm{CH}_{3} \mathrm{COOH}$, and (c) $\mathrm{O}_{2}$ pressure on $1 \mathrm{wt} . \% \mathrm{Pd} / \mathrm{SiO}_{2}$ catalyst at $433 \mathrm{~K}$. 
S9. Effect of switching between labeled and unlabeled reactants om VA formation rates The KIE values reported in Table 2, Main Text were derived from data shown in Figure S13.
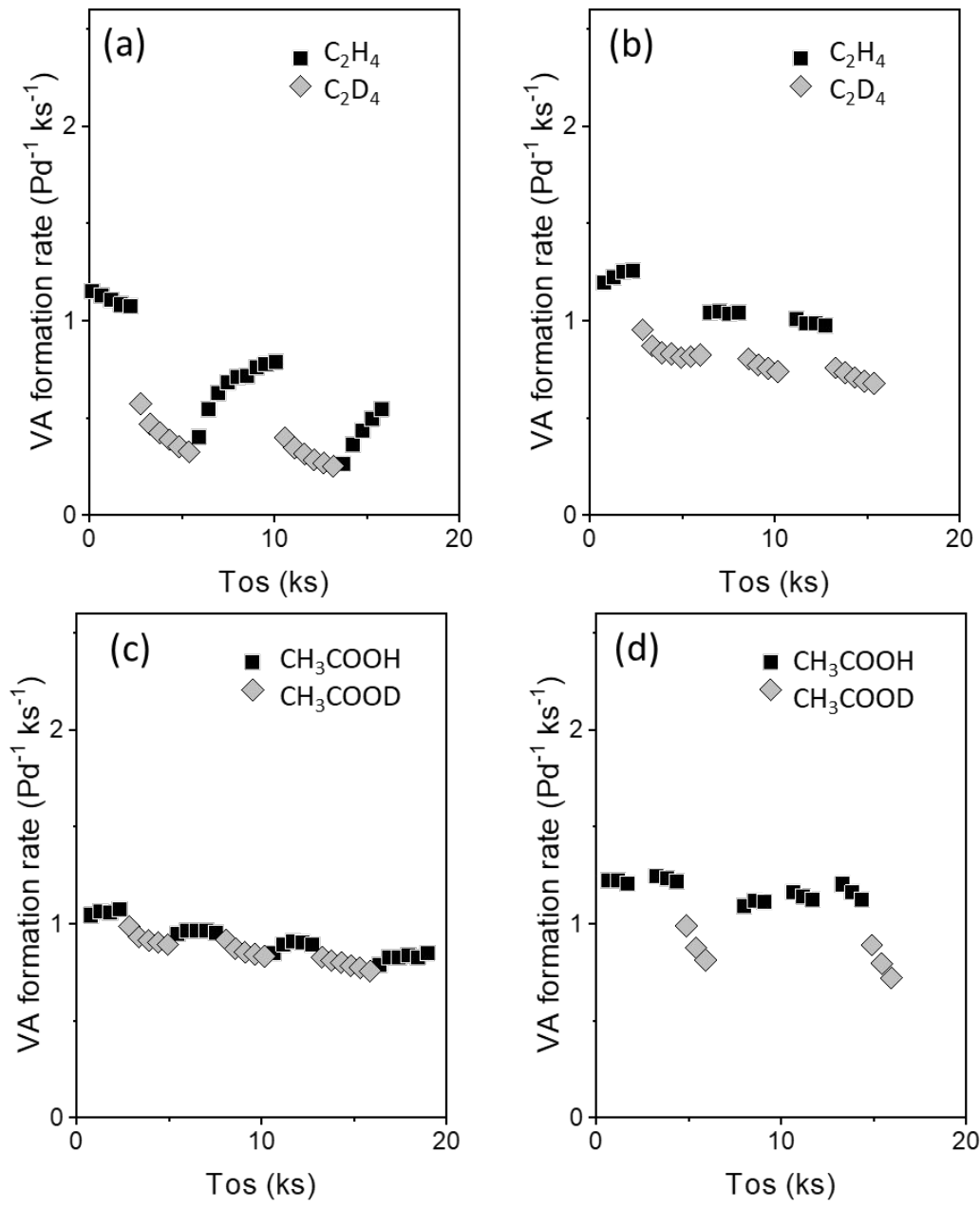

Figure S13. VA formations rates as a function of time on stream when normal reactant (black square) and isotopic reactant (orange diamond) were used. These data showed comparison between VA rates of $\mathrm{C}_{2} \mathrm{H}_{4} / \mathrm{C}_{2} \mathrm{D}_{4}$ (a) and $\mathrm{CH}_{3} \mathrm{COOH} / \mathrm{CH}_{3} \mathrm{COOD}$ (b) under $40 \mathrm{kPa} \mathrm{C}_{2} \mathrm{H}_{4}, 12 \mathrm{kPa}$ $\mathrm{CH}_{3} \mathrm{COOH}, 5 \mathrm{kPa} \mathrm{O}$ (i) and $10 \mathrm{kPa} \mathrm{C}_{2} \mathrm{H}_{4}, 35 \mathrm{kPa} \mathrm{CH} \mathrm{COOH}_{3} 6 \mathrm{kPa} \mathrm{O}$ (ii) with a total flow rate $40 \mathrm{cc} \mathrm{min}^{-1}$ and $433 \mathrm{~K}$. 


\section{S10. Enthalpy and entropy calculations}

Enthalpy and entropy were calculated at $433 \mathrm{~K}, 10 \mathrm{kPa} \mathrm{C}_{2} \mathrm{H}_{4}, \mathrm{CH}_{3} \mathrm{COOH}$ and $\mathrm{O}_{2}$ and $10 \mathrm{PaCO}$, using ideal gas statistical mechanics. Enthalpy represents the sum of DFT-derived electronic energy $\left(E_{0}\right)$, zero-point vibrational energy $(Z P E)$ and vibrational $\left(H_{\text {vib }}\right)$, translational $\left(H_{\text {trans }}\right)$ and rotational $\left(H_{r o t}\right)$ contributions:

$$
H=E_{0}+Z P E+H_{v i b}+H_{\text {trans }}+H_{\text {rot }}
$$

Entropy is given by the sum of the electronic $\left(\mathrm{S}_{0}\right)$, vibrational $\left(S_{\text {vib }}\right)$, translational $\left(S_{\text {trans }}\right)$ and rotational $\left(S_{\text {rot }}\right)$ contributions:

$$
S=S_{0}+S_{\text {vib }}+S_{\text {trans }}+S_{\text {rot }}
$$

The free energy at a given temperature $(T)$ is given by:

$$
G=H-T S
$$

The zero-point vibrational energy $(Z P E)$, vibrational enthalpy $\left(H_{v i b}\right)$ and vibrational entropy $\left(S_{v i b}\right)$ are given by:

$$
\begin{gathered}
Z P E=\sum_{i 2}^{1} h v_{i} \\
H_{v i b}=\sum_{i}\left(\frac{h v_{i} e^{\frac{-h v_{i}}{k T}}}{1-e^{\frac{-h v_{i}}{k T}}}\right) \\
S_{v i b}=\sum_{i}\left(\frac{h v_{i} / T e^{\frac{-h v_{i}}{k T}}}{1-e^{\frac{-h v_{i}}{k T}}}-k \ln \left(1-e^{\frac{-h v_{i}}{k T}}\right)\right)
\end{gathered}
$$

where, $h, k$, and $v$ represent Plank constant, Boltzmann constant and vibrational frequency, respectively.

The translational and rotational enthalpy and entropy components are given by:

$$
\begin{gathered}
H_{\text {trans }}=\frac{5}{2} k T \\
H_{\text {rot }}=\frac{3}{2} k T \\
S_{\text {trans }}=k\left(\ln \left(\left(\frac{2 \pi m k T}{h^{2}}\right)^{3 / 2} V\right)+\frac{5}{2}\right) \\
S_{\text {rot }}=k\left(\ln \left(\frac{\pi^{1 / 2}}{\sigma}\left(\frac{T^{3}}{\theta_{x} \theta_{y} \theta_{z}}\right)^{1 / 2}\right)+\frac{3}{2}\right) \\
\theta_{1 / 2 / 3}=\frac{h^{2}}{8 \pi^{2} I_{1 / 2 / 3} k}
\end{gathered}
$$

where, $m$ and $V$ are mass and volume per molecule, $I_{1}, I_{2}$ and $I_{3}$ are the moments of inertia with respect to the three aces of rotation for a given molecule, respectively, and $\sigma$ is the rotational symmetry number.

Most surface species do not have and translational or rotational contributions. Vibrational frequencies below $65 \mathrm{~cm}^{-1}$ were excluded from entropy and enthalpy contributions for all surface species. Some surfaces species exhibited fewer or more low-frequency vibrational modes $(<65$ $\mathrm{cm}^{-1}$ ) than the reference state in the $\Delta \mathrm{H}$ or $\Delta \mathrm{S}$ calculations. These differences were removed by replacing the additional low-frequency modes with $70 \%$ of the translational and rotational contribution per mode $\left(1 / 6^{\text {th }}\right.$ of the total translational + rotational enthalpy or entropy) of the gaseous species involved in a given $\Delta \mathrm{H}$ or $\Delta \mathrm{S}$ calculation. 
S11. DFT derived minimum energy path and barrier for acetate hopping

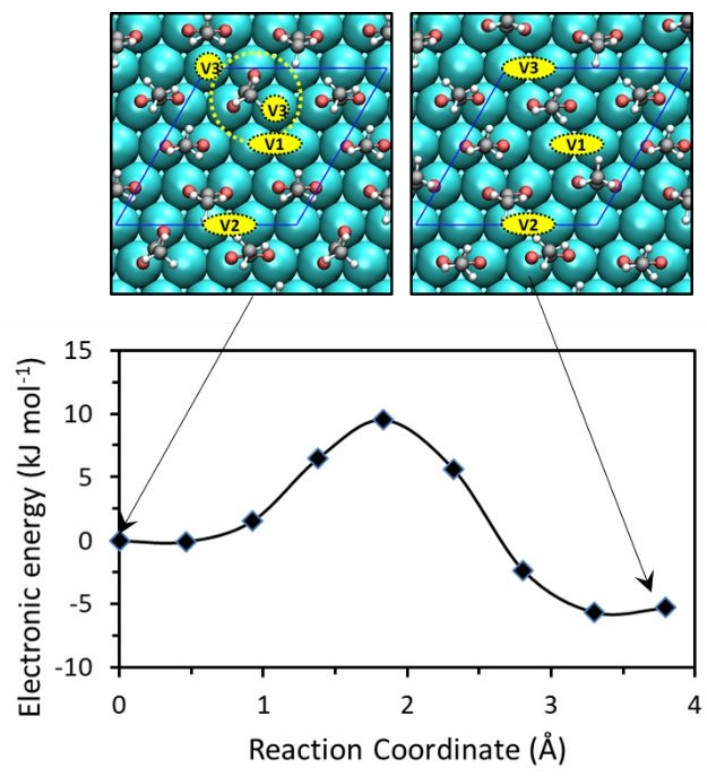

Figure S14. Minimum energy path for acetate shift at 5/16 coverage derived from NEB calculations. The initial and final structures correspond to Fig. $\mathbf{6 b}$ and $\mathbf{6 a}$, respectively, in Main Text. NEB calculations were performed using 3-layer $\mathrm{Pd}(111), 400 \mathrm{eV}$ plane-wave cutoff, $3 \times 3 \times$ 1 k-points, climbing image (CI) method and $0.05 \mathrm{eV} \AA^{-1}$ force convergence. Subsequent Dimer calculation led to a $9.5 \mathrm{~kJ} \mathrm{~mol}^{-1}$ barrier, which is identical to the CI-NEB barrier. 


\section{S12. AIMD calculations for determining stable adsorbate configurations}

Most stable configurations of (i) acetate covered surface at 5/16 coverage, (ii) $\mathrm{C}_{2} \mathrm{H}_{4}$ adsorbed at $5 / 16$ acetate coverage, and (iii) $\mathrm{CH}_{3} \mathrm{COOH}$ adsorbed at 5/16 acetate coverage, found via geometry optimization were used as starting points of $\mathrm{Ab}$ initio molecular dynamics (AIMD) calculations to check if even more stable configurations can be found. The AIMD calculations were performed with 2 fs time steps and temperature fluctuations around $433 \mathrm{~K}$ using the Nosé algorithm. ${ }^{\mathrm{S} 13}$ The input parameters NSW $=1000, \mathrm{IBRION}=0, \mathrm{POTIM}=2, \mathrm{SMASS}=0$, TEBEG $=433$, TEEND $=433$ were used in these simulations.
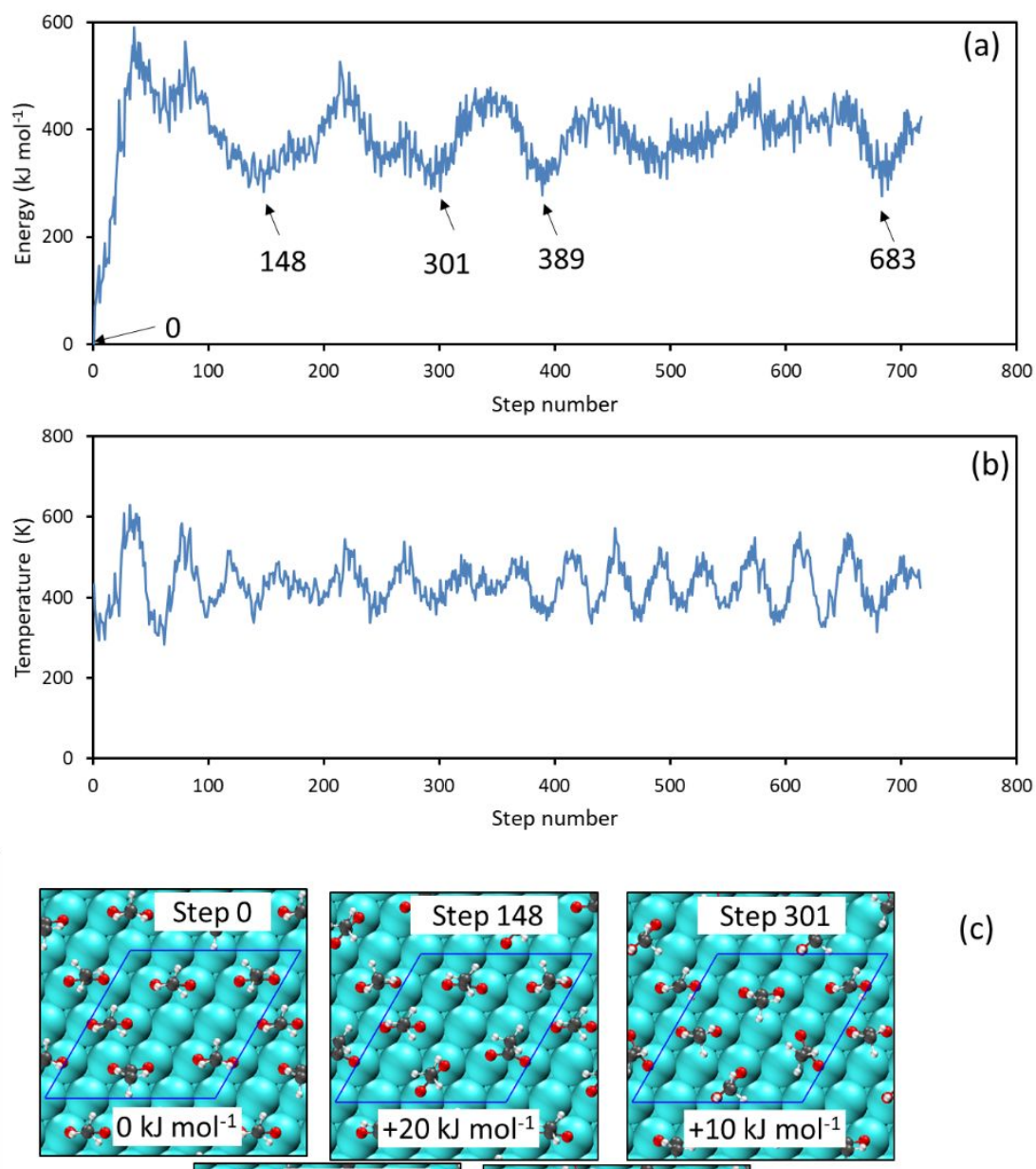

(c)

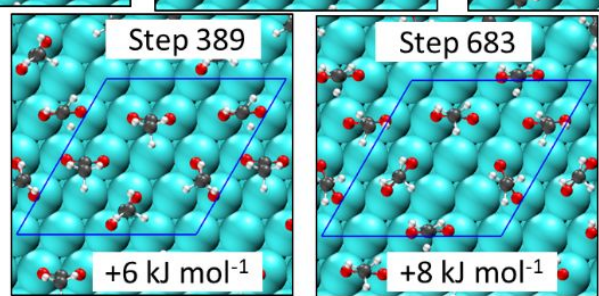

Figure S15. (a) Energy (relative to the initial structure in step 0) and (b) temperature as a function of AIMD steps for 5/16 acetate covered surface. The initial structure corresponds to Figure 5a in Main Text. Structures in some steps were used for geometry optimization, and their optimized structures and energies are shown in (c). All calculations used a 3-layer slab, $400 \mathrm{eV}$ plane-wave cutoff, $3 \times 3 \times 1$ k-points, and $0.05 \mathrm{eV}^{-1}$ force convergence in geometry optimization. 
Table S5. Energies of different configurations of $\operatorname{Pd}(111)$ surface with $5 / 16$ acetate coverage relative to the first structure.

\begin{tabular}{|c|c|c|}
\hline \multirow{2}{*}{ Structure } & \multicolumn{2}{|c|}{ Energy $\left(\mathrm{kJ} \mathrm{mol}^{-1}\right)$} \\
\cline { 2 - 3 } & Method $1^{\mathrm{a}}$ & Method 2 $^{\mathrm{b}}$ \\
\hline Figure 5a & 0 & 0 \\
\hline Figure 5b & 6 & 5 \\
\hline Figure 5c & 8 & 0.5 \\
\hline Figure 5d & 3 & \\
\hline Optimized from AIMD step 148 & 20 & \\
\hline Optimized from AIMD step 301 & 10 & \\
\hline Optimized from AIMD step 389 & 6 & \\
\hline Optimized from AIMD step 683 & 8 & \\
\hline
\end{tabular}

a 3-layer slab, $400 \mathrm{eV}$ plane-wave cutoff, $3 \times 3 \times 1$ k-points, and $0.05 \mathrm{eV} \AA^{-1}$ force convergence

b 4-layer slab, $500 \mathrm{eV}$ plane-wave cutoff, $4 \times 4 \times 1$ k-points, and $0.025 \mathrm{eV}^{-1}$ force convergence 

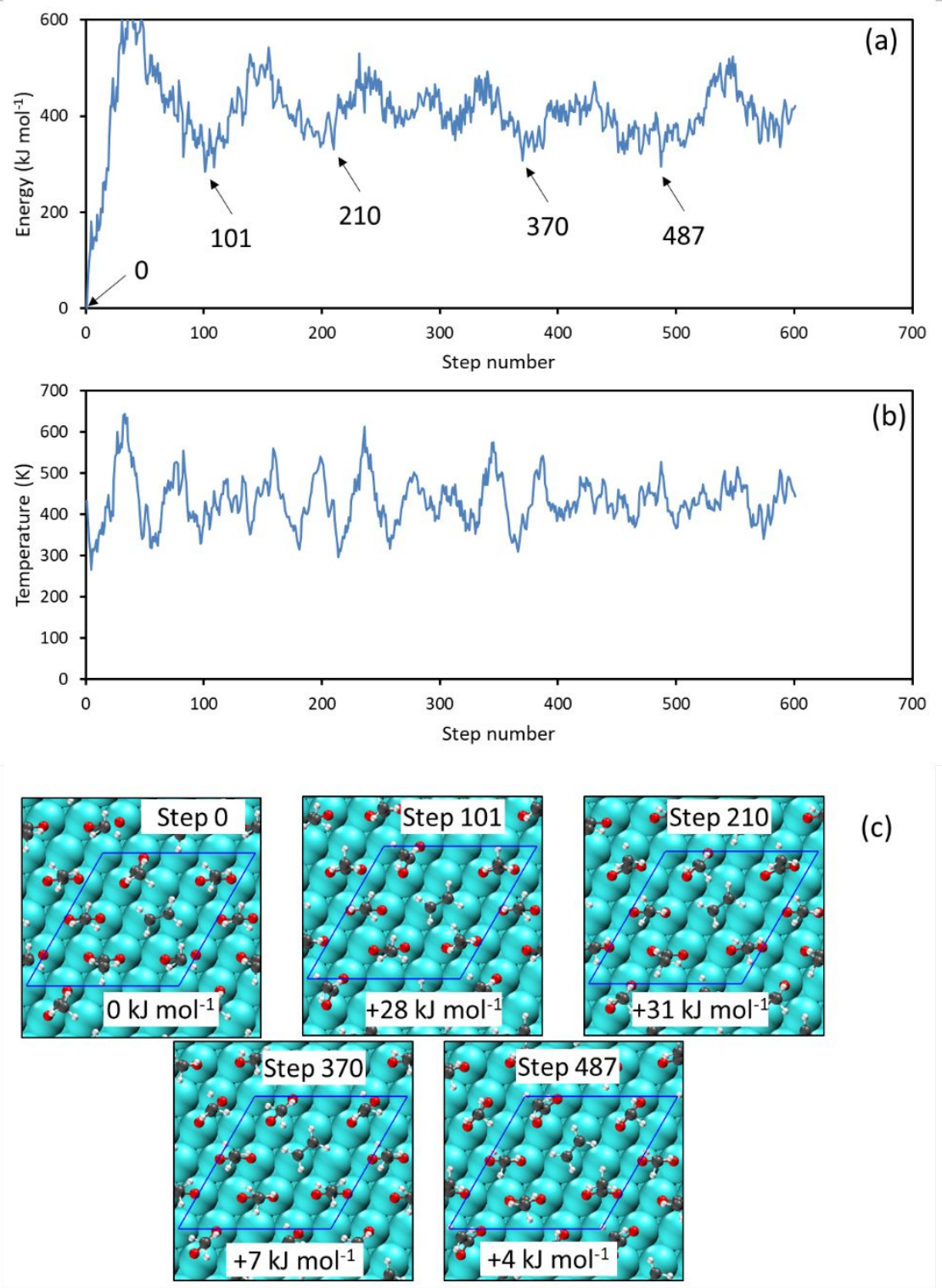

(c)

Figure S16. (a) Energy (relative to the initial structure in step 0) and (b) temperature as a function of AIMD steps for $\mathrm{C}_{2} \mathrm{H}_{4} *$ species at $5 / 16$ acetate coverage. The initial structure corresponds to the $\mathrm{C}_{2} \mathrm{H}_{4}$ * structure in Figure 6c in Main Text. Structures in some steps were used for geometry optimization, and their optimized structures and energies are shown in (c). All calculations used a 3-layer slab, $400 \mathrm{eV}$ plane-wave cutoff, $3 \times 3 \times 1$ k-points, and $0.05 \mathrm{eV} \AA^{-1}$ force convergence in geometry optimization. 

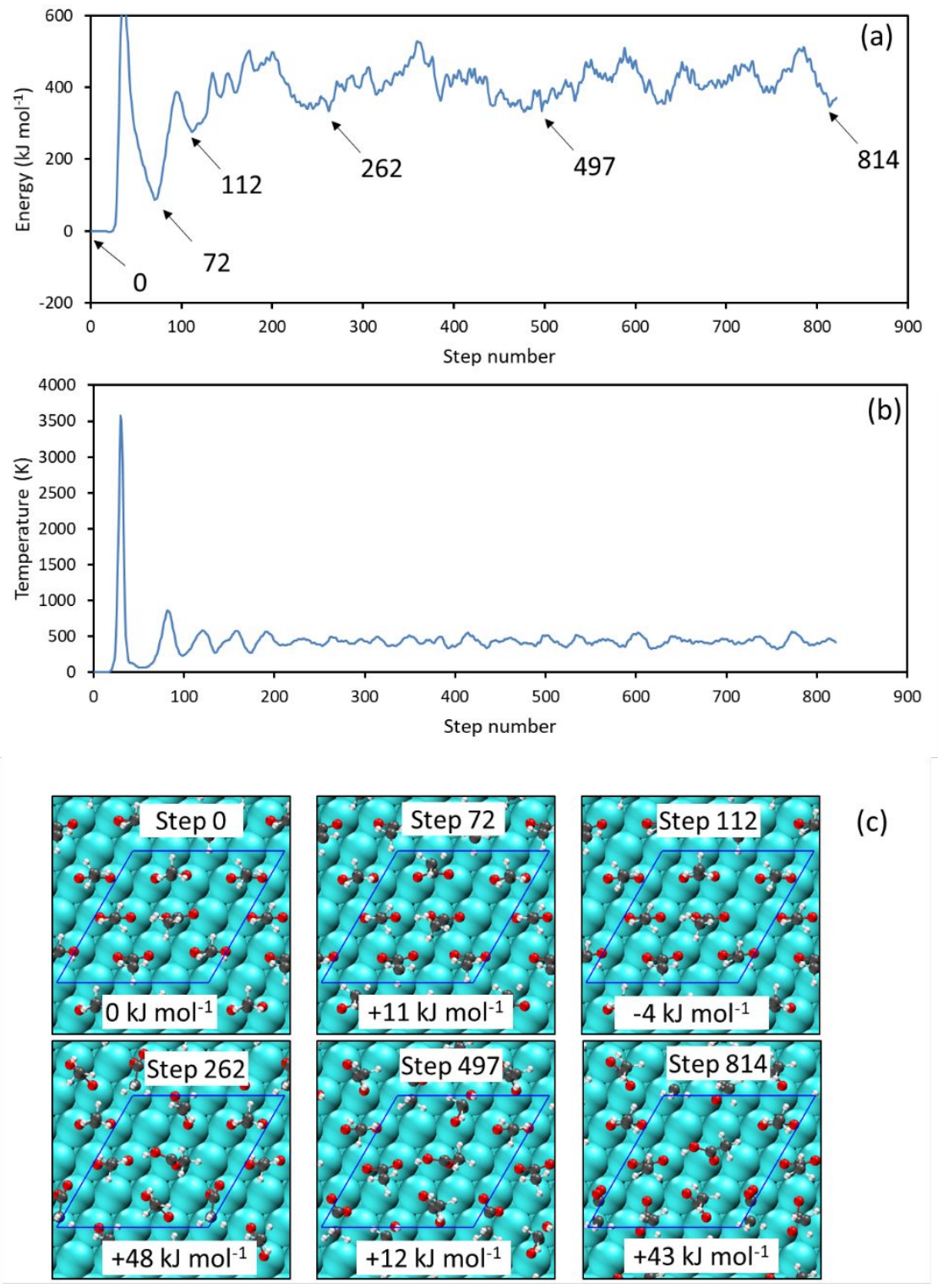

(c)

Figure S17. (a) Energy (relative to the initial structure in step 0) and (b) temperature as a function of AIMD steps for $\mathrm{CH}_{3} \mathrm{COOH}^{*}$ species at 5/16 acetate coverage. The initial structure corresponds to the $\mathrm{CH}_{3} \mathrm{COOH}^{*}$ structure in Figure 6c in Main Text. Structures in some steps were used for geometry optimization, and their optimized structures and energies are shown in (c). All calculations used a 3-layer slab, $400 \mathrm{eV}$ plane-wave cutoff, $3 \times 3 \times 1$ k-points, and 0.05 $\mathrm{eV} \AA^{-1}$ force convergence in geometry optimization. 


\section{S13. Effect of acetate coverage on $\mathrm{CH}_{3} \mathrm{COOH}, \mathrm{O}_{2}, \mathrm{C}_{2} \mathrm{H}_{4}$ and $\mathrm{CO}$ adsorption energies and their van der Waals components}

Table S6. PBE-D3BJ derived electronic energies of formation for molecularly adsorbed $\mathrm{CH}_{3} \mathrm{COOH}, \mathrm{O}_{2}, \mathrm{C}_{2} \mathrm{H}_{4}$ and $\mathrm{CO}$ from gaseous molecules on $\mathrm{Pd}(111)$ surface with $1 / 16,5 / 16,6 / 16$ and $7 / 16$ acetate coverage. Values in brackets show van der Waals contribution to formation energies. Images show structures for $6 / 16$ coverage.

\begin{tabular}{ccccc}
\hline & \multicolumn{3}{c}{ Formation energy [vdW contribution] $\left(\mathrm{kJ} \mathrm{mol}^{-1}\right)$} \\
\cline { 2 - 5 } & & & & \\
Acetate & & & & \\
coverage & $\mathrm{CH}_{3} \mathrm{COOH}^{*}$ & $\mathrm{O}_{2}{ }^{*}$ & $\mathrm{C}_{2} \mathrm{H}_{4}{ }^{*}$ & $\mathrm{CO}$ \\
\hline $1 / 16$ & $-90[-48]$ & $-100[-24]$ & $-142[-54]$ & $-222[-27]$ \\
$5 / 16$ & $-90[-77]$ & $-97[-36]$ & $-139[-78]$ & $-229[-43]$ \\
$6 / 16$ & $-4[-86]$ & $-64[-48]$ & $-53[-90]$ & $-123[-45]$ \\
$7 / 16$ & $10[-96]$ & $-20[-39]$ & $22[-92]$ & $-111[-49]$ \\
\hline
\end{tabular}

Table S6 shows energies of formation of molecular adsorbates $\left(\mathrm{CH}_{3} \mathrm{COOH}, \mathrm{O}_{2}, \mathrm{C}_{2} \mathrm{H}_{4}\right.$ and $\left.\mathrm{CO}\right)$ at the acetate vacancy labeled as V1 in Figure 4 (Main Text) for 1/16, 5/16, 6/16 and 7/16 coverage. The $\mathrm{CH}_{3} \mathrm{COOH}^{*}$ species binds to the top of a $\mathrm{Pd}$ atom via the O-atom with the $\mathrm{O}-\mathrm{H}$ bond and is $\mathrm{H}$-bonded to a vicinal acetate on the left of the V1 vacancy. $\mathrm{C}_{2} \mathrm{H}_{4}$ and $\mathrm{O}_{2}$ bind with one $\mathrm{C}$ and $\mathrm{O}$ atom, respectively, each on top of one $\mathrm{Pd}$ atom. $\mathrm{CO}$ is adsorbed at the bridging location between two $\mathrm{Pd}$ atoms. At the low coverage of $1 / 16, \mathrm{C}_{2} \mathrm{H}_{4} *$ exhibits more negative adsorption energy than $\mathrm{O}_{2}{ }^{*}$ and $\mathrm{CH}_{3} \mathrm{COOH}^{*}\left(-142,-100\right.$ and $-90 \mathrm{~kJ} \mathrm{~mol}^{-1}$, respectively; Table S6), and the energy for $\mathrm{CO}^{*}$ is much more negative than all three reactants $\left(-222 \mathrm{~kJ} \mathrm{~mol}^{-1}\right)$. The formation energies for all species are nearly the same at $1 / 16$ and $5 / 16$ coverages, which indicates that they do not depend significantly on coverage below the 5/16 coverage. As in the case of bound acetates, the formation energies of molecular adsorbates are much less negative at $6 / 16$ and $7 / 16$ than at 5/16 coverage (Table S6). This decrease in stability with coverage, however, is more significant for molecules with larger cross-section area on the surface, leading to less stable $\mathrm{C}_{2} \mathrm{H}_{4} *$ and $\mathrm{CH}_{3} \mathrm{COOH}^{*}$ than $\mathrm{O}_{2}{ }^{*}$ at $6 / 16$ and $7 / 16$ coverage. $\mathrm{CO} *$ remains the most stable surface species at all coverages, consistent with $\mathrm{CO}$ inhibition effects detected in our measurements.

Table S6 also shows the van der Waals (vdW) stabilization component of the adsorption energies. These $\mathrm{vdW}$ components at $5 / 16$ coverages are more negative than at $1 / 16$ coverage by $13-29 \mathrm{~kJ} \mathrm{~mol}^{-1}$, suggesting that the coverage insensitivity for adsorption below $5 / 16$ coverage is a result of the compensation between weaker binding via electronic interaction with the surface and a stronger adsorbate-adsorbate $\mathrm{vdW}$ interactions. Thus, accurate accounting of the $\mathrm{vdW}$ interactions is essential for accurately capturing the coverage effects. The vdW components change monotonically and become more negative at higher coverage, but the more significant destabilization due to the electronic and steric factors sharply lowers the overall stability of species beyond $5 / 16$ coverage. 


\section{S14. DFT derived proton hopping steps and O-H activation barriers}

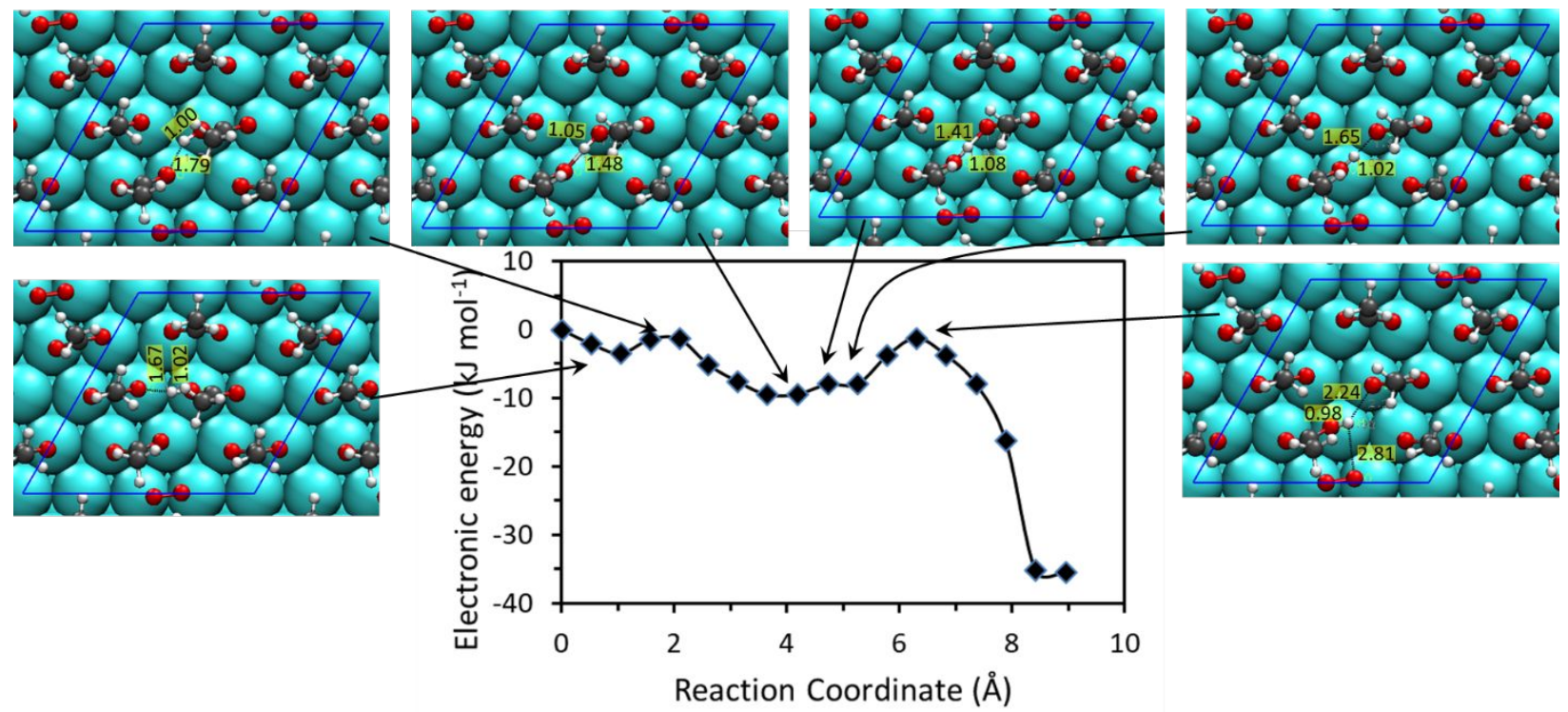

Figure S18. Minimum energy path for proton shuttling from $\mathrm{CH}_{3} \mathrm{COOH}$ to acetate species and from $\mathrm{CH}_{3} \mathrm{COOH}$ to $\mathrm{O}_{2}$ species at 5/16 coverage derived from NEB calculations. The very low barriers for such shuttling processes confirm that proton shuttling from distant locations to $\mathrm{O}_{2}$ derived species will be very rapid and the $\mathrm{O}_{2}$ derived reactive intermediates can be rapidly consumed by this process. NEB calculations were performed using 3-layer $\operatorname{Pd}(111), 400 \mathrm{eV}$ plane-wave cutoff, $3 \times 3 \times 1$ k-points, climbing image $(\mathrm{CI})$ method and $0.05 \mathrm{eV} \AA^{-1}$ force convergence.

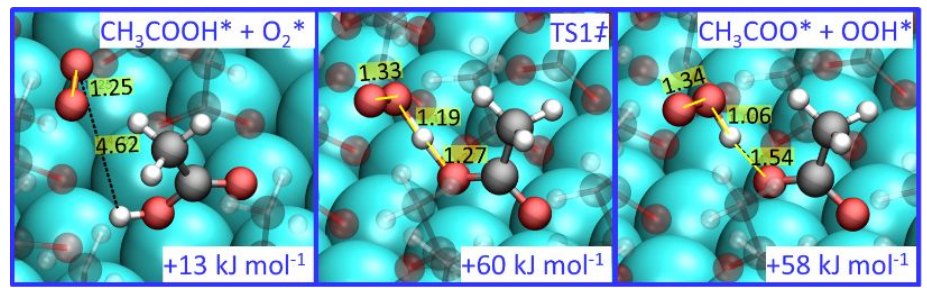

Figure S19. Structures and energies for acetate formation via $\mathrm{O}-\mathrm{H}$ in $\mathrm{CH}_{3} \mathrm{COOH}^{*}$ by physisorbed $\mathrm{O}_{2}$ at $7 / 16$ coverage (Fig. S20). This reaction step runs out of surface sites at 7/16 coverage for $\mathrm{O}_{2} *$ to form on the surface, which requires this alternate path. All other reaction steps at 7/16 and 6/16 coverages have structures analogous to that shown in Fig. 6c in Main Text for $5 / 16$ coverage. 
S15. Energies as a function of reaction coordinate for acetate formation, $\mathrm{O}_{2}$ dissociation and $V A$ formation at $7 / 16$ coverage
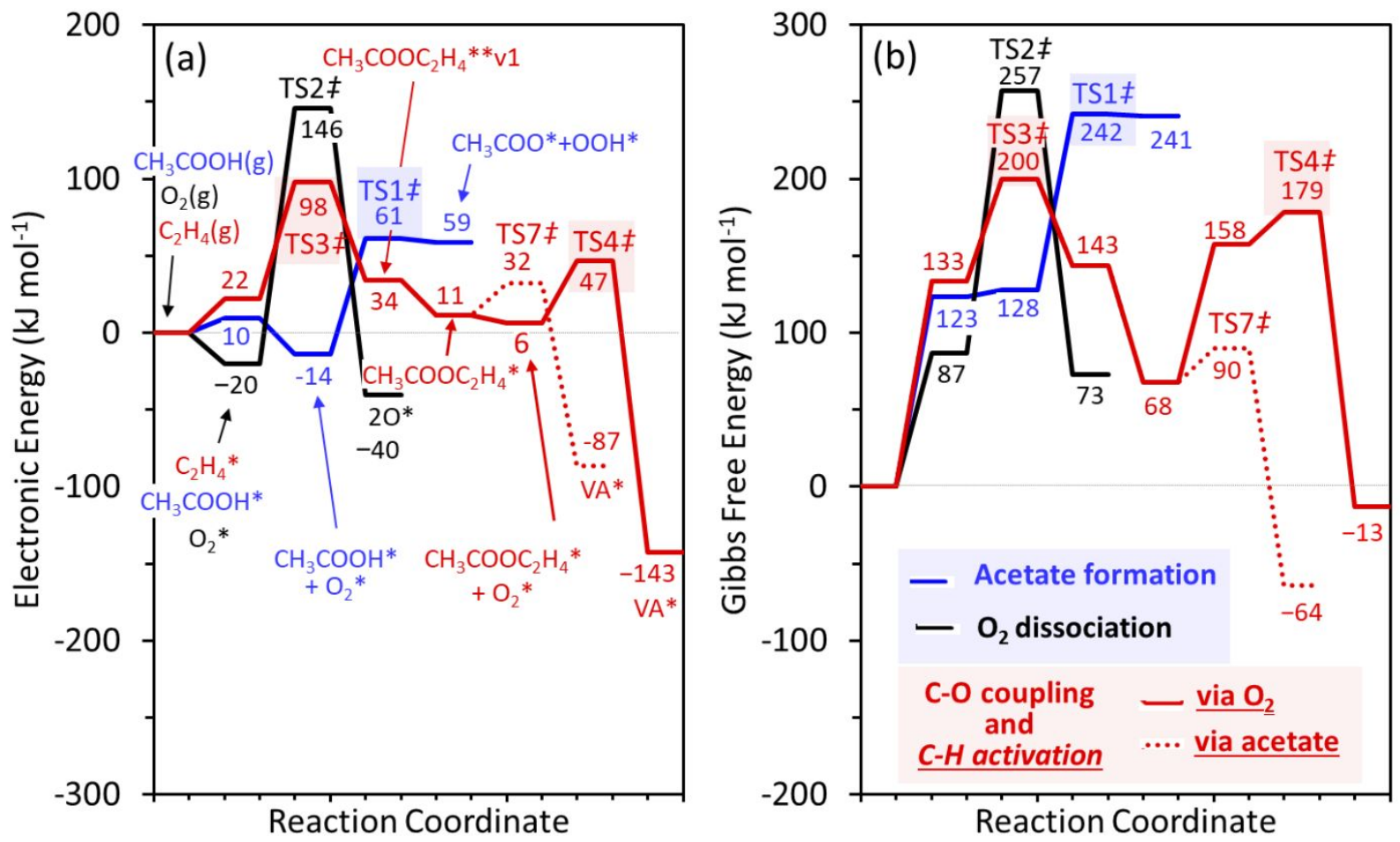

Figure S20. PBE-D3BJ derived (a) electronic energies, and (b) free energies (at 433K and 10 $\mathrm{kPa}$ pressure of all gaseous species) for intermediates and transition states involved in acetate formation, $\mathrm{O}_{2}$ dissociation, $\mathrm{CO}$ coupling and $\mathrm{C}-\mathrm{H}$ activation for $\mathrm{VA}$ formation at 7/16 acetate coverage. See Figure 6c in Main Text for representative structures of species.

Figure S20 shows electronic energies and free energies of reactive intermediates and transition states for acetate formation, $\mathrm{O}_{2}$ dissociation, $\mathrm{C}-\mathrm{O}$ coupling and $\mathrm{C}-\mathrm{H}$ activation at 7/16 acetate coverage at the V1 site. The structures in these calculations are analogous to those for $5 / 16$ and $6 / 16$ coverage of all surface species, except for the acetate formation step that is impacted by the absence of the V2 vacancy at this coverage. For this case, the $\mathrm{O}-\mathrm{H}$ activation in $\mathrm{CH}_{3} \mathrm{COOH}^{*}$ adsorbed at the V1 site occurs via $\mathrm{H}$-abstraction by a $\mathrm{O}_{2}$ physisorbed near the V1 site without any direct contact to the surface Pd sites (Fig. S19). The highly crowded surface at this coverage leads to less negative adsorption and activation energy for all species, with the exception of the transition state for $\mathrm{H}$-abstraction in acetoxyethyl by a vicinal acetate, which becomes much lower in energy than its value at the $6 / 16$ coverage and becomes the most prevalent path for $\mathrm{C}-\mathrm{H}$ activation. 
S16. Effect of coverage on intrinsic C-O coupling barriers
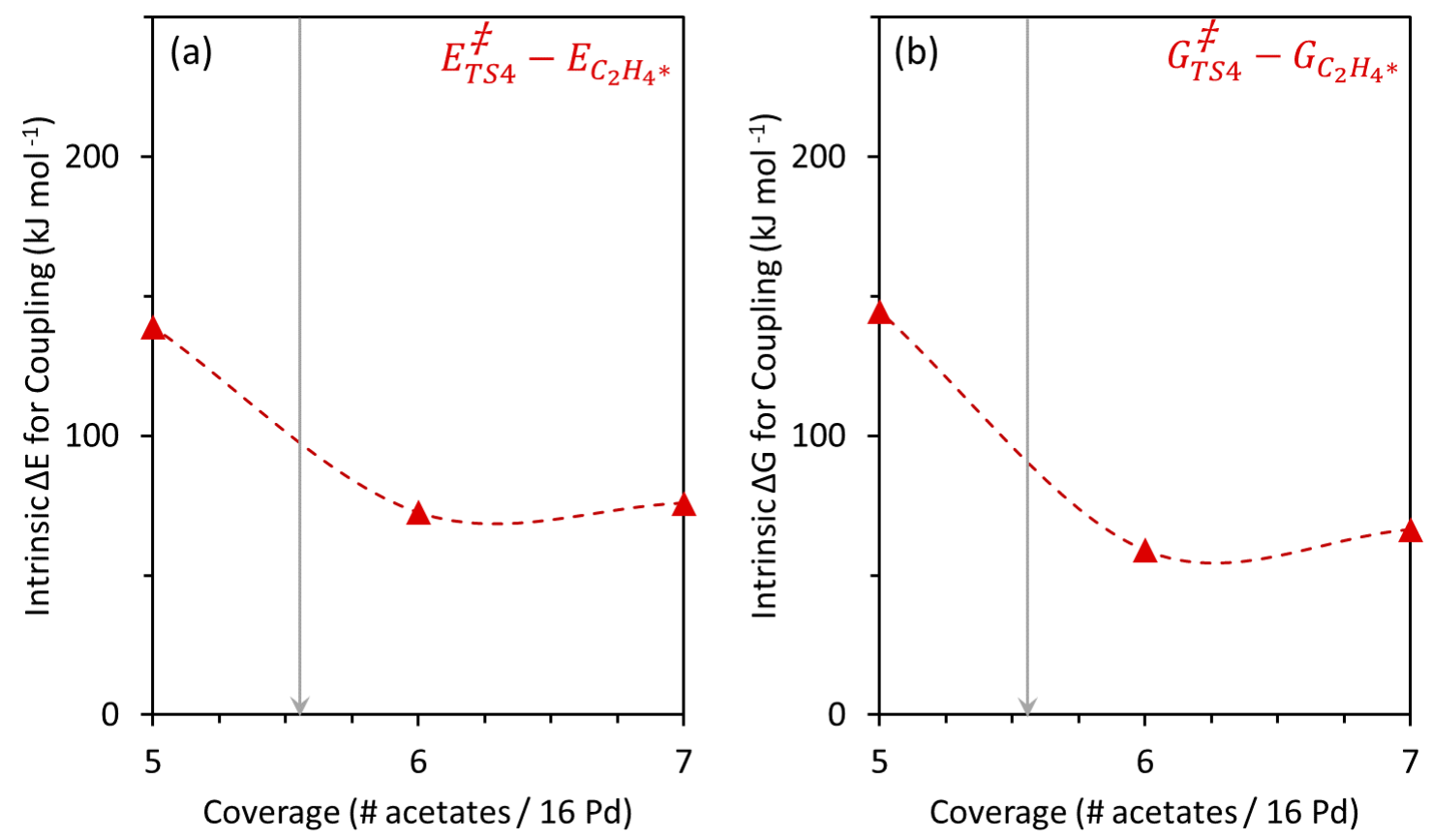

Figure S21. Effect of coverage on intrinsic C-O coupling barrier. 
S17. Electronic energies, enthalpies, entropies and free energies of reactive intermediates and transition states

Table S7. PBE-D3BJ derived electronic energy $(\Delta E)$, enthalpy $(\Delta H)$, entropy $(\Delta S)$, Gibbs free energy $(\Delta G ; 433 \mathrm{~K}, 10 \mathrm{kPa}$ pressure of all gaseous species) for intermediates and transition states involved in acetate formation, $\mathrm{O}_{2}$ dissociation and VA formation at 5/16 coverage.

\begin{tabular}{|c|c|c|c|c|}
\hline Species & $\begin{array}{c}\Delta E \\
\left(\mathrm{~kJ} \mathrm{~mol}^{-1}\right)\end{array}$ & $\begin{array}{c}\Delta H \\
\left(\mathrm{~kJ} \mathrm{~mol}^{-1}\right)\end{array}$ & $\begin{array}{c}\Delta S \\
\left(\mathrm{~J} \mathrm{~mol}^{-1} \mathrm{~K}^{-1}\right)\end{array}$ & $\begin{array}{c}\Delta G \\
\left(\mathrm{~kJ} \mathrm{~mol}^{-1}\right)\end{array}$ \\
\hline & \multicolumn{4}{|c|}{ Acetate Formation } \\
\hline $\mathrm{CH}_{3} \mathrm{COOH}^{*}$ & -90 & -85 & -208 & 5 \\
\hline $\mathrm{CH}_{3} \mathrm{COOH}^{*}+\mathrm{O}_{2} *$ & -149 & -141 & -394 & 29 \\
\hline TS1 & -149 & -150 & -423 & 33 \\
\hline \multirow[t]{2}{*}{$\mathrm{CH}_{3} \mathrm{COO}^{*}+\mathrm{OOH}^{*}$} & -188 & -175 & -438 & 15 \\
\hline & \multicolumn{4}{|c|}{$\mathrm{O}_{2}$ dissociation } \\
\hline $\mathrm{O}_{2}$ * & -97 & -93 & -177 & -17 \\
\hline TS2 & -37 & -41 & -174 & 35 \\
\hline \multirow[t]{2}{*}{$2 \mathrm{O}^{*}$} & -194 & -189 & -214 & -96 \\
\hline & \multicolumn{4}{|c|}{ VA formation } \\
\hline $\mathrm{C}_{2} \mathrm{H}_{4} *$ & -139 & -132 & -208 & -42 \\
\hline TS3 & -0.1 & 3 & -212 & 95 \\
\hline $\mathrm{CH}_{3} \mathrm{COOC}_{2} \mathrm{H}_{4} * * \mathrm{v} 1$ & -44 & -34 & -206 & 55 \\
\hline $\mathrm{CH}_{3} \mathrm{COOC}_{2} \mathrm{H}_{4} *$ & -17 & -13 & -136 & 46 \\
\hline $\mathrm{CH}_{3} \mathrm{COOC}_{2} \mathrm{H}_{4} * * \mathrm{v} 1+\mathrm{O}_{2} *$ & -112 & -107 & -302 & 24 \\
\hline TS4 & -40 & -48 & -351 & 104 \\
\hline $\mathrm{VA}^{*}+\mathrm{OOH}^{*}$ & -99 & -93 & -272 & 24 \\
\hline TS5 & 20 & 26 & -228 & 125 \\
\hline $\mathrm{CH}_{3} \mathrm{COOC}_{2} \mathrm{H}_{4}{ }^{* *} \mathrm{v} 2$ & -19 & -12 & -202 & 75 \\
\hline TS6 & 19 & 11 & -197 & 96 \\
\hline $\mathrm{VA}^{*+\mathrm{H}^{*}}$ & -20 & -19 & -194 & 65 \\
\hline TS7 & 145 & 125 & -124 & 179 \\
\hline $\mathrm{VA}^{*+}+\mathrm{H}\left(\mathrm{CH}_{3} \mathrm{COO}\right)^{*}$ & 71 & 80 & -81 & 115 \\
\hline
\end{tabular}


Table S8. PBE-D3BJ derived electronic energy $(\Delta E)$, enthalpy $(\Delta H)$, entropy $(\Delta S)$, Gibbs free energy $(\Delta G ; 433 \mathrm{~K}, 10 \mathrm{kPa}$ pressure of all gaseous species) for intermediates and transition states involved in acetate formation, $\mathrm{O}_{2}$ dissociation and VA formation at 6/16 coverage.

\begin{tabular}{|c|c|c|c|c|}
\hline Species & $\begin{array}{c}\Delta E \\
\left(\mathrm{~kJ} \mathrm{~mol}^{-1}\right)\end{array}$ & $\begin{array}{c}\Delta H \\
\left(\mathrm{~kJ} \mathrm{~mol}^{-1}\right)\end{array}$ & $\begin{array}{c}\Delta S \\
\left(\mathrm{~J} \mathrm{~mol}^{-1} \mathrm{~K}^{-1}\right)\end{array}$ & $\begin{array}{c}\Delta G \\
\left(\mathrm{~kJ} \mathrm{~mol}^{-1}\right)\end{array}$ \\
\hline & \multicolumn{4}{|c|}{ Acetate Formation } \\
\hline $\mathrm{CH}_{3} \mathrm{COOH}^{*}$ & -4 & -1 & -243 & 105 \\
\hline $\mathrm{CH}_{3} \mathrm{COOH}^{*}+\mathrm{O}_{2} *$ & -68 & -63 & -439 & 127 \\
\hline TS1 & -51 & -53 & -466 & 149 \\
\hline \multirow[t]{2}{*}{$\mathrm{CH}_{3} \mathrm{COO}^{*+} \mathrm{OOH}^{*}$} & -56 & -47 & -451 & 149 \\
\hline & \multicolumn{4}{|c|}{$\mathrm{O}_{2}$ dissociation } \\
\hline $\mathrm{O}_{2} *$ & -64 & -63 & -196 & 22 \\
\hline TS2 & 102 & 99 & -213 & 191 \\
\hline \multirow[t]{2}{*}{$2 \mathrm{O}^{*}$} & -127 & -124 & -229 & -24 \\
\hline & \multicolumn{4}{|c|}{ VA formation } \\
\hline $\mathrm{C}_{2} \mathrm{H}_{4} *$ & -53 & -48 & -237 & 55 \\
\hline TS3 & 19 & 17 & -206 & 107 \\
\hline $\mathrm{CH}_{3} \mathrm{COOC}_{2} \mathrm{H}_{4}^{* *} \mathrm{v} 1$ & -33 & -30 & -175 & 46 \\
\hline $\mathrm{CH}_{3} \mathrm{COOC}_{2} \mathrm{H}_{4} *$ & -10 & -12 & -118 & 40 \\
\hline $\mathrm{CH}_{3} \mathrm{COOC}_{2} \mathrm{H}_{4} * * v 1+\mathrm{O}_{2} *$ & -101 & 5 & 2 & 47 \\
\hline TS4 & -29 & 6 & 3 & 97 \\
\hline $\mathrm{VA}^{*}+\mathrm{OOH}^{*}$ & -115 & 7 & 4 & 10 \\
\hline TS5 & 25 & 26 & -202 & 114 \\
\hline $\mathrm{CH}_{3} \mathrm{COOC}_{2} \mathrm{H}_{4} * *$ v2 & -17 & -11 & -213 & 81 \\
\hline TS6 & 18 & 7 & -194 & 91 \\
\hline $\mathrm{VA}^{*+\mathrm{H}^{*}}$ & -7 & -14 & -161 & 56 \\
\hline TS7 & 121 & 99 & -116 & 149 \\
\hline $\mathrm{VA}^{*+\mathrm{H}}\left(\mathrm{CH}_{3} \mathrm{COO}\right)^{*}$ & 44 & 49 & -54 & 72 \\
\hline
\end{tabular}


Table S9. PBE-D3BJ derived electronic energy $(\Delta E)$, enthalpy $(\Delta H)$, entropy $(\Delta S)$, Gibbs free energy $(\Delta G ; 433 \mathrm{~K}, 10 \mathrm{kPa}$ pressure of all gaseous species) for intermediates and transition states involved in acetate formation, $\mathrm{O}_{2}$ dissociation and VA formation at 7/16 coverage.

\begin{tabular}{|c|c|c|c|c|}
\hline Species & $\begin{array}{c}\Delta E \\
\left(\mathrm{~kJ} \mathrm{~mol}^{-1}\right)\end{array}$ & $\begin{array}{c}\Delta H \\
\left(\mathrm{~kJ} \mathrm{~mol}^{-1}\right)\end{array}$ & $\begin{array}{c}\Delta S \\
\left(\mathrm{~J} \mathrm{~mol}^{-1} \mathrm{~K}^{-1}\right)\end{array}$ & $\begin{array}{c}\Delta G \\
\left(\mathrm{~kJ} \mathrm{~mol}^{-1}\right)\end{array}$ \\
\hline & \multicolumn{4}{|c|}{ Acetate Formation } \\
\hline $\mathrm{CH}_{3} \mathrm{COOH}^{*}$ & 10 & 17 & -244 & 123 \\
\hline $\mathrm{CH}_{3} \mathrm{COOH}^{*}+\mathrm{O}_{2} *$ & -14 & -10 & -318 & 128 \\
\hline TS1 & 61 & 61 & -419 & 242 \\
\hline \multirow[t]{2}{*}{$\mathrm{CH}_{3} \mathrm{COO}^{*+}+\mathrm{OOH}^{*}$} & 59 & 67 & -402 & 241 \\
\hline & \multicolumn{4}{|c|}{$\mathrm{O}_{2}$ dissociation } \\
\hline $\mathrm{O}_{2}$ * & -20 & -13 & -231 & 87 \\
\hline TS2 & 146 & 149 & -252 & 257 \\
\hline \multirow[t]{2}{*}{$2 \mathrm{O}^{*}$} & -40 & -32 & -243 & 73 \\
\hline & \multicolumn{4}{|c|}{ VA formation } \\
\hline $\mathrm{C}_{2} \mathrm{H}_{4} *$ & 22 & 31 & -236 & 133 \\
\hline TS3 & 98 & 103 & -223 & 200 \\
\hline $\mathrm{CH}_{3} \mathrm{COOC}_{2} \mathrm{H}_{4} * * \mathrm{v} 1$ & 34 & 49 & -218 & 143 \\
\hline $\mathrm{CH}_{3} \mathrm{COOC}_{2} \mathrm{H}_{4} *$ & 11 & 17 & -118 & 68 \\
\hline $\mathrm{CH}_{3} \mathrm{COOC}_{2} \mathrm{H}_{4} * * \mathrm{v} 1+\mathrm{O}_{2} *$ & 6 & 15 & -329 & 158 \\
\hline TS4 & 47 & 37 & -327 & 179 \\
\hline $\mathrm{VA}^{*}+\mathrm{OOH}^{*}$ & -143 & -136 & -282 & -13 \\
\hline TS7 & 32 & 21 & -159 & 90 \\
\hline $\mathrm{VA}^{*+\mathrm{H}}\left(\mathrm{CH}_{3} \mathrm{COO}\right)^{*}$ & -87 & -85 & -49 & -64 \\
\hline
\end{tabular}




\section{S18. Effect of calculation methods on electronic energies}

Table S10. PBE-D3BJ derived electronic energy $(\Delta E)$ for intermediates and transition states involved in acetate formation, $\mathrm{O}_{2}$ dissociation and VA formation at $\mathbf{5 / 1 6}$ coverage for low and high accuracy methods.

\begin{tabular}{|c|c|c|}
\hline \multirow[t]{2}{*}{ Species } & \multicolumn{2}{|c|}{$\Delta E\left(\mathrm{~kJ} \mathrm{~mol}^{-1}\right)$} \\
\hline & Method $1^{\mathrm{a}}$ & Method $2^{b}$ \\
\hline & \multicolumn{2}{|c|}{ Acetate Formation } \\
\hline $\mathrm{CH}_{3} \mathrm{COOH}^{*}$ & -95 & -90 \\
\hline $\mathrm{CH}_{3} \mathrm{COOH}^{*+\mathrm{O}_{2}} *$ & -161 & -149 \\
\hline TS1 & -160 & -149 \\
\hline $\mathrm{CH}_{3} \mathrm{COO}^{*+\mathrm{OOH}^{*}}$ & -202 & -188 \\
\hline \multicolumn{3}{|c|}{$\mathrm{O}_{2}$ dissociation } \\
\hline $\mathrm{O}_{2} *$ & -108 & -97 \\
\hline TS2 & -53 & -37 \\
\hline $2 \mathrm{O}^{*}$ & -207 & -194 \\
\hline \multicolumn{3}{|c|}{ VA formation } \\
\hline $\mathrm{C}_{2} \mathrm{H}_{4} *$ & -147 & -139 \\
\hline TS3 & -6 & -0.1 \\
\hline $\mathrm{CH}_{3} \mathrm{COOC}_{2} \mathrm{H}_{4} * * \mathrm{v} 1$ & -45 & -44 \\
\hline $\mathrm{CH}_{3} \mathrm{COOC}_{2} \mathrm{H}_{4} *$ & -13 & -17 \\
\hline $\mathrm{CH}_{3} \mathrm{COOC}_{2} \mathrm{H}_{4} * * v 1+\mathrm{O}_{2} *$ & -116 & -112 \\
\hline TS4 & -46 & -40 \\
\hline $\mathrm{VA}^{*}+\mathrm{OOH}^{*}$ & -103 & -99 \\
\hline TS5 & 24 & 20 \\
\hline $\mathrm{CH}_{3} \mathrm{COOC}_{2} \mathrm{H}_{4}{ }^{* *} \mathrm{v} 2$ & -15 & -19 \\
\hline TS6 & 19 & 19 \\
\hline $\mathrm{VA}^{*+\mathrm{H}^{*}}$ & -18 & -20 \\
\hline TS7 & 155 & 145 \\
\hline $\mathrm{VA}^{*+\mathrm{H}}\left(\mathrm{CH}_{3} \mathrm{COO}\right)^{*}$ & 86 & 71 \\
\hline
\end{tabular}

a 3-layer slab, $400 \mathrm{eV}$ plane-wave cutoff, $3 \times 3 \times 1$ k-points, and $0.05 \mathrm{eV} \AA^{-1}$ force convergence

b 4-layer slab, $500 \mathrm{eV}$ plane-wave cutoff, $4 \times 4 \times 1 \mathrm{k}$-points, and $0.025 \mathrm{eV}^{-1}$ force convergence 
Table S11. PBE-D3BJ derived electronic energy $(\Delta E)$ for intermediates and transition states involved in acetate formation, $\mathrm{O}_{2}$ dissociation and VA formation at 6/16 coverage for low and high accuracy methods.

\begin{tabular}{|c|c|c|}
\hline \multirow[t]{2}{*}{ Species } & \multicolumn{2}{|c|}{$\Delta E\left(\mathrm{~kJ} \mathrm{~mol}^{-1}\right)$} \\
\hline & Method 1a & Method $2^{b}$ \\
\hline & \multicolumn{2}{|c|}{ Acetate Formation } \\
\hline $\mathrm{CH}_{3} \mathrm{COOH}^{*}$ & -8 & -4 \\
\hline $\mathrm{CH}_{3} \mathrm{COOH}^{*}+\mathrm{O}_{2}{ }^{*}$ & -66 & -68 \\
\hline TS1 & -62 & -51 \\
\hline $\mathrm{CH}_{3} \mathrm{COO}^{*+}+\mathrm{OOH}^{*}$ & -70 & -56 \\
\hline \multicolumn{3}{|c|}{$\mathrm{O}_{2}$ dissociation } \\
\hline $\mathrm{O}_{2} *$ & -53 & -64 \\
\hline TS2 & 94 & 102 \\
\hline $2 \mathrm{O}^{*}$ & -130 & -127 \\
\hline \multicolumn{3}{|c|}{ VA formation } \\
\hline $\mathrm{C}_{2} \mathrm{H}_{4} *$ & -43 & -53 \\
\hline TS3 & 17 & 19 \\
\hline $\mathrm{CH}_{3} \mathrm{COOC}_{2} \mathrm{H}_{4}{ }^{* *} \mathrm{v} 1$ & -28 & -33 \\
\hline $\mathrm{CH}_{3} \mathrm{COOC}_{2} \mathrm{H}_{4} *$ & -16 & -10 \\
\hline $\mathrm{CH}_{3} \mathrm{COOC}_{2} \mathrm{H}_{4} * * \mathrm{v} 1+\mathrm{O}_{2} *$ & -97 & -101 \\
\hline TS4 & -34 & -29 \\
\hline $\mathrm{VA}^{*}+\mathrm{OOH}^{*}$ & -113 & -115 \\
\hline TS5 & 30 & 25 \\
\hline $\mathrm{CH}_{3} \mathrm{COOC}_{2} \mathrm{H}_{4} * * \mathrm{v} 2$ & -12 & -17 \\
\hline TS6 & 21 & 18 \\
\hline $\mathrm{VA}^{*+\mathrm{H}^{*}}$ & 5 & -7 \\
\hline TS7 & 134 & 121 \\
\hline $\mathrm{VA}^{*+}+\mathrm{H}\left(\mathrm{CH}_{3} \mathrm{COO}\right)^{*}$ & 63 & 44 \\
\hline
\end{tabular}

a 3-layer slab, $400 \mathrm{eV}$ plane-wave cutoff, $3 \times 3 \times 1 \mathrm{k}$-points, and $0.05 \mathrm{eV} \AA^{-1}$ force convergence

b 4-layer slab, $500 \mathrm{eV}$ plane-wave cutoff, $4 \times 4 \times 1$ k-points, and $0.025 \mathrm{eV}^{-1}$ force convergence 
Table S12. PBE-D3BJ derived electronic energy $(\Delta E)$ for intermediates and transition states involved in acetate formation, $\mathrm{O}_{2}$ dissociation and VA formation at 7/16 coverage for low and high accuracy methods.

\begin{tabular}{|c|c|c|}
\hline \multirow[t]{2}{*}{ Species } & \multicolumn{2}{|c|}{$\Delta E\left(\mathrm{~kJ} \mathrm{~mol}^{-1}\right)$} \\
\hline & Method $1^{\mathrm{a}}$ & Method $2^{\mathrm{b}}$ \\
\hline & \multicolumn{2}{|c|}{ Acetate Formation } \\
\hline $\mathrm{CH}_{3} \mathrm{COOH}^{*}$ & 6 & 10 \\
\hline $\mathrm{CH}_{3} \mathrm{COOH}^{*}+\mathrm{O}_{2}{ }^{*}$ & -15 & -14 \\
\hline TS1 & 60 & 61 \\
\hline $\mathrm{CH}_{3} \mathrm{COO}^{*}+\mathrm{OOH}^{*}$ & 55 & 59 \\
\hline \multicolumn{3}{|c|}{$\mathrm{O}_{2}$ dissociation } \\
\hline $\mathrm{O}_{2} *$ & -34 & -20 \\
\hline TS2 & 135 & 146 \\
\hline $2 \mathrm{O}^{*}$ & -48 & -40 \\
\hline \multicolumn{3}{|c|}{ VA formation } \\
\hline $\mathrm{C}_{2} \mathrm{H}_{4} *$ & 18 & 22 \\
\hline TS3 & 95 & 98 \\
\hline $\mathrm{CH}_{3} \mathrm{COOC}_{2} \mathrm{H}_{4} * * \mathrm{v} 1$ & 36 & 34 \\
\hline $\mathrm{CH}_{3} \mathrm{COOC}_{2} \mathrm{H}_{4} *$ & 14 & 11 \\
\hline $\mathrm{CH}_{3} \mathrm{COOC}_{2} \mathrm{H}_{4} * * \mathrm{v} 1+\mathrm{O}_{2} *$ & 3 & 6 \\
\hline TS4 & 43 & 47 \\
\hline $\mathrm{VA}^{*}+\mathrm{OOH}^{*}$ & -141 & -143 \\
\hline TS7 & 40 & 32 \\
\hline $\mathrm{VA}^{*+}+\mathrm{H}\left(\mathrm{CH}_{3} \mathrm{COO}\right)^{*}$ & -72 & -87 \\
\hline
\end{tabular}

a 3-layer slab, $400 \mathrm{eV}$ plane-wave cutoff, $3 \times 3 \times 1$ k-points, and $0.05 \mathrm{eV}^{-1}$ force convergence

b 4-layer slab, $500 \mathrm{eV}$ plane-wave cutoff, $4 \times 4 \times 1$ k-points, and $0.025 \mathrm{eV} \AA^{-1}$ force convergence 
S19. Effect of atom perturbation length on vibrational frequencies and thermodynamic contributions

Table S13. Effect of perturbation length on frequencies, ZPVE, vibrational enthalpy and vibrational entropy. All calculations in Main Text use $0.01 \AA$ perturbation. Frequencies below 65 $\mathrm{cm}^{-1}$ are excluded and substituted by contributions from gas-phase molecules.

\begin{tabular}{|c|c|c|}
\hline \multirow[t]{2}{*}{ Mode number / Quantity } & \multicolumn{2}{|c|}{ Frequency $\left(\mathrm{cm}^{-1}\right)$, Energy $\left(\mathrm{kJ} \mathrm{mol}^{-1}\right)$, Entropy $\left(\mathrm{J} \mathrm{mol}^{-1} \mathrm{~K}^{-1}\right)$} \\
\hline & $0.01 \AA ̊$ perturbation & 0.02 A perturbation \\
\hline 1 & 3104 & 3104 \\
\hline 2 & 3103 & 3104 \\
\hline 3 & 3101 & 3102 \\
\hline 4 & 3101 & 3102 \\
\hline 5 & 3100 & 3100 \\
\hline 6 & 3078 & 3079 \\
\hline 7 & 3075 & 3076 \\
\hline 8 & 3065 & 3066 \\
\hline 9 & 3065 & 3066 \\
\hline 10 & 3064 & 3065 \\
\hline 11 & 2995 & 2997 \\
\hline 12 & 2993 & 2996 \\
\hline 13 & 2986 & 2989 \\
\hline 14 & 2983 & 2987 \\
\hline 15 & 2982 & 2985 \\
\hline 16 & 1480 & 1482 \\
\hline 17 & 1476 & 1475 \\
\hline 18 & 1474 & 1473 \\
\hline 19 & 1472 & 1471 \\
\hline 20 & 1469 & 1469 \\
\hline 21 & 1436 & 1435 \\
\hline 22 & 1430 & 1429 \\
\hline 23 & 1429 & 1428 \\
\hline 24 & 1428 & 1426 \\
\hline 25 & 1425 & 1424 \\
\hline 26 & 1422 & 1421 \\
\hline 27 & 1412 & 1411 \\
\hline 28 & 1411 & 1409 \\
\hline 29 & 1408 & 1407 \\
\hline 30 & 1403 & 1402 \\
\hline 31 & 1359 & 1360 \\
\hline 32 & 1352 & 1352 \\
\hline 33 & 1350 & 1352 \\
\hline 34 & 1349 & 1350 \\
\hline 35 & 1346 & 1347 \\
\hline 36 & 1331 & 1330 \\
\hline 37 & 1325 & 1324 \\
\hline 38 & 1325 & 1323 \\
\hline 39 & 1319 & 1318 \\
\hline 40 & 1317 & 1317 \\
\hline 41 & 1017 & 1016 \\
\hline 42 & 1016 & 1015 \\
\hline 43 & 1015 & 1014 \\
\hline 44 & 1014 & 1013 \\
\hline 45 & 1009 & 1008 \\
\hline 46 & 1000 & 998 \\
\hline 47 & 998 & 997 \\
\hline 48 & 997 & 997 \\
\hline 49 & 997 & 996 \\
\hline 50 & 996 & 995 \\
\hline 51 & 922 & 922 \\
\hline 52 & 922 & 921 \\
\hline 53 & 920 & 920 \\
\hline 54 & 918 & 918 \\
\hline 55 & 917 & 917 \\
\hline 56 & 651 & 650 \\
\hline 57 & 649 & 648 \\
\hline 58 & 646 & 645 \\
\hline & S37 & \\
\hline
\end{tabular}




\begin{tabular}{|c|c|c|}
\hline $\begin{array}{l}59 \\
60\end{array}$ & $\begin{array}{l}644 \\
641\end{array}$ & $\begin{array}{l}644 \\
642\end{array}$ \\
\hline 61 & 588 & 587 \\
\hline 62 & 587 & 585 \\
\hline 63 & 583 & 583 \\
\hline 64 & 581 & 582 \\
\hline 65 & 577 & 576 \\
\hline 66 & 510 & 511 \\
\hline 67 & 508 & 506 \\
\hline 68 & 506 & 505 \\
\hline 69 & 500 & 500 \\
\hline 70 & 499 & 498 \\
\hline 71 & 248 & 251 \\
\hline 72 & 242 & 242 \\
\hline 73 & 238 & 239 \\
\hline 74 & 227 & 230 \\
\hline 75 & 221 & 226 \\
\hline 76 & 215 & 212 \\
\hline $\begin{array}{l}77 \\
78\end{array}$ & $\begin{array}{l}210 \\
201\end{array}$ & $\begin{array}{l}208 \\
199\end{array}$ \\
\hline 79 & $\begin{array}{l}201 \\
198\end{array}$ & 197 \\
\hline 80 & 197 & 195 \\
\hline 81 & 189 & 187 \\
\hline 82 & 183 & 179 \\
\hline 83 & 168 & 164 \\
\hline 84 & 154 & 149 \\
\hline 85 & 147 & 139 \\
\hline 86 & 138 & 132 \\
\hline 87 & 136 & 128 \\
\hline 88 & 127 & 127 \\
\hline 89 & 124 & 122 \\
\hline 90 & 118 & 117 \\
\hline 91 & 117 & 112 \\
\hline 92 & 112 & 107 \\
\hline 93 & 109 & 104 \\
\hline 94 & 105 & 98 \\
\hline 95 & 102 & 95 \\
\hline 96 & 99 & 93 \\
\hline 97 & 97 & 90 \\
\hline 98 & 89 & 87 \\
\hline 99 & 84 & 77 \\
\hline 100 & 82 & 74 \\
\hline 101 & 80 & 66 \\
\hline 102 & 74 & 55 \\
\hline 103 & 55 & 50 \\
\hline 104 & 41 & 47 \\
\hline 105 & -28 & -56 \\
\hline ZPVE (kJ mol-1) & 651.4 & 650.2 \\
\hline Vibrational Enthalpy $\left(\mathrm{kJ} \mathrm{mol}^{-1}\right)$ & 118.2 & 115.6 \\
\hline Vibrational Entropy $\left(\mathrm{J} \mathrm{mol}^{-1} \mathrm{~K}^{-1}\right)$ & 565.3 & 554.2 \\
\hline
\end{tabular}




\section{References}

S1. Hanrieder, E. K.; Jentys, A.; Lercher, J. A., Atomistic Engineering of Catalyst Precursors: Dynamic Reordering of PdAu Nanoparticles during Vinyl Acetate Synthesis Enhanced by Potassium Acetate. ACS Catal. 2015, 5, 5776-5786.

S2. Ojeda, M.; Iglesia, E., Catalytic Epoxidation of Propene with $\mathrm{H}_{2} \mathrm{O}-\mathrm{O}_{2}$ Reactants on $\mathrm{Au} / \mathrm{TiO}{ }_{2}$. Chem. Commun. 2009, 352-354.

S3. Kolasinski, K. W.; Cemic, F.; Hasselbrink, E., $\mathrm{O}_{2} / \mathrm{Pd}$ ( 111). Clarification of the Correspondence Between Thermal Desorption Features and Chemisorption states. Chem. Phys. Lett. 1994, 219, 113-117.

S4. Huang, Y.; Dong, X.; Yu, Y.; Zhang, M., The Influence of Surface Oxygen and Hydroxyl Groups on the Dehydrogenation of Ethylene, Acetic Acid and Hydrogenated Vinyl Acetate on Pure Pd(1 0 0): A DFT Study. Appl. Surf. Sci. 2016, 388, 455-460.

S5. $\quad$ Hyung Chul Ham; Hwang, G. S.; Han, J.; Nam, S. W.; Lim, T. H., On the Role of Pd Ensembles in Selective $\mathrm{H}_{2} \mathrm{O}_{2}$ Formation on PdAu Alloys. J. Phys. Chem. C 2009, 113, 12943-12945.

S6. Ham, H. C.; Stephens, J. A.; Hwang, G. S.; Han, J.; Nam, S. W.; Lim, T. H., Pd Ensemble Effects on Oxygen Hydrogenation in AuPd Alloys: A Combined Density Functional Theory and Monte Carlo Study. Catal. Today 2011, 165, 138-144.

S7. $\quad$ Saavedra, J.; Doan, H. A.; Pursell, C. J.; Grabow, L. C.; Chandler, B. D., The Critical Role of Water at the Gold-titania Interface in Catalytic CO Oxidation. Science 2014, 345, 1599-1602.

S8. $\quad$ Saavedra, J.; Whittaker, T.; Chen, Z.; Pursell, C. J.; Rioux, R. M.; Chandler, B. D., Controlling Activity and Selectivity Using Water in the Au-catalysed Preferential Oxidation of $\mathrm{CO}$ in $\mathrm{H}_{2}$. Nat. Chem. 2016, 8, 584-589.

S9. Saavedra, J.; Pursell, C. J.; Chandler, B. D., CO Oxidation Kinetics over $\mathrm{Au} / \mathrm{TiO}{ }_{2}$ and $\mathrm{Au} / \mathrm{Al}_{2} \mathrm{O}_{3}$ Catalysts: Evidence for a Common Water-Assisted Mechanism. J. Am. Chem. Soc. 2018, 140, 3712-3723. S10. Wilson, N. M.; Flaherty, D. W., Mechanism for the Direct Synthesis of $\mathrm{H}_{2} \mathrm{O}_{2}$ on Pd Clusters: Heterolytic Reaction Pathways at the Liquid-Solid Interface. J. Am. Chem. Soc. 2016, 138, 574-586.

S11. Bregante, D. T.; Thornburg, N. E.; Notestein, J. M.; Flaherty, D. W., Consequences of Confinement for Alkene Epoxidation with Hydrogen Peroxide on Highly Dispersed Group 4 and 5 Metal Oxide Catalysts. ACS Catal. 2018, 8, 2995-3010.

S12. Moiseev, I.; Vargaftik, M.; Syrhim, Y., On the Mechanism of the Reaction of Palladium Salts with Olefines in Hydroxyl-containing Solutions. Dokl. Akad. Nauk 1960, 133, 377-380.

S13. Nosé, S., A Unified Formulation of the Constant Temperature Molecular Dynamics Methods. $J$. Chem. Phys. 1984, 81, 511-519. 